\title{
Remote hydroacoustic-infrasonic detection and characterization of Anak Krakatau eruptive activity leading to, during, and following the December 2018 flank collapse and tsunami
}

\author{
Kaelynn M. Rose ${ }^{1} \cdot$ Robin S. Matoza $^{1}$ (D)
}

Received: 2 January 2021 / Accepted: 18 May 2021 / Published online: 13 July 2021

(c) The Author(s) 2021

\begin{abstract}
A climactic eruption phase on December 22, 2018, triggered the collapse of the southwest flank and summit of Anak Krakatau stratovolcano, generating a tsunami which struck the coastlines of Sumatra and Java. We employ a selection of remote moored hydroacoustic (H08S, $3307 \mathrm{~km}$; H01W, $3720 \mathrm{~km}$ ) and infrasonic (IS06, $1156 \mathrm{~km}$; IS07, $3475 \mathrm{~km}$; IS52, $3638 \mathrm{~km}$ ) stations of the International Monitoring System (IMS) to investigate eruptive activity preceding, during, and after the climactic eruption phase. We observe 6 months of co-eruptive intermittent infrasound at IS06 and powerful infrasound from the climactic eruption on IS06 and IS52. The climactic eruption phase was not detected hydroacoustically, but we observe a 12-day swarm of hydroacoustic signals beginning 24 days before the flank collapse event that we attribute to sustained submarine eruptive activity at Anak Krakatau. We perform hydroacoustic waveform and envelope multiplet analysis to assess event similarity during the hydroacoustic swarm. Hydroacoustic waveforms are not well-correlated, but envelopes with a main pulse duration of 20 -s are correlated, with $88.7 \%$ of 247 events grouping into two multiplets using a threshold correlation coefficient of 0.75 . The repetitive envelopes indicate a repetitive impulsive volcanic process, either underwater submarine explosions or volcanic earthquakes in the solid Earth coupled to the water column from the Sunda Shelf. This study further underscores the potential of remote acoustic technology for detecting and characterizing eruptions at submarine or partially submerged volcanoes.
\end{abstract}

Keywords Anak Krakatau $\cdot$ Infrasound $\cdot$ Hydroacoustics $\cdot$ Submarine eruption $\cdot$ Explosive volcanism

\section{Introduction}

Anak Krakatau (Child of Krakatau) is a highly active basaltic to dacitic stratovolcano located on the rim of the caldera formed by the 1883 paroxysmal eruption of Krakatau in the Sunda Strait of Indonesia (Fig. 1; Camus et al. 1987; Stehn 1929). Anak Krakatau is a partially submerged volcano, defined here as a volcano which rises from the seafloor, with some part of the upper volcanic edifice that has emerged above the sea surface as an island. A new eruptive phase

Editorial responsibility: W. W. Chadwick, Jr.

Kaelynn M. Rose

kaelynn@ucsb.edu

Robin S. Matoza

rmatoza@ucsb.edu

1 Department of Earth Science and Earth Research Institute, University of California, Santa Barbara, CA, USA began on June 18, 2018, followed by 6 months of intermittent explosive eruption activity (Global Volcanism Program 2019). The eruption peaked on December 22, 2018, with a period of intense eruption triggering a flank collapse and a powerful tsunami in the Sunda Strait (Global Volcanism Program 2019; Grilli et al. 2019). As the eruption included a period of intense Strombolian activity, a tsunamigenic flank collapse, and $\sim 19$ days of Surtseyan eruption activity, this new eruptive phase is an opportunity to investigate an eruption using both remote infrasound and remote hydroacoustic technology. Prior to this event, infrasound from a shallow submarine explosive eruption had rarely been reported (e.g., Global Volcanism Program 2004; Green et al. 2013; Lyons et al. 2020) and volcanic flank collapses are rare events which have few recordings in the geophysical record (e.g., Kanamori and Given 1982; Eissler and Kanamori 1987; Green and Neuberg 2005; Watts et al. 2012).

Regarding terminology, the Smithsonian Global Volcanism Program (GVP) bulletin (Global Volcanism Program 


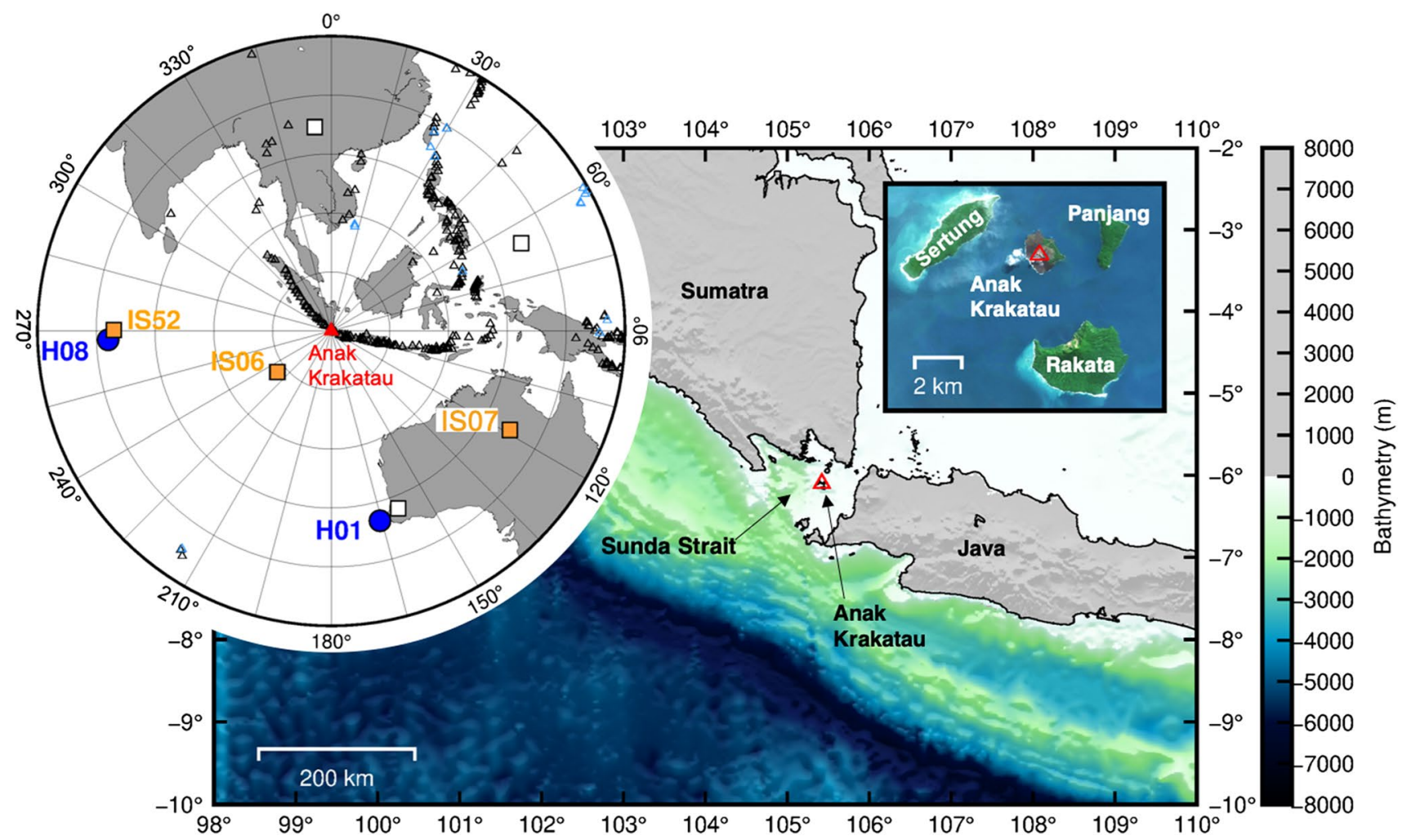

Fig. 1 The location of Anak Krakatau volcano (red triangle) in the Sunda Strait, Indonesia, and IMS infrasound and hydroacoustic stations. Infrasound stations are shown as squares, and hydroacoustic stations are shown as circles; filled symbols are stations used in this study. On the azimuthal map, the open black triangles show locations of potentially active subaerial volcanoes, and the open blue triangles show locations of submarine volcanoes (Global Volcanism Program

2019) and existing literature to date refer variously to the December 2018 Krakatau collapse event as a flank collapse (Williams et al. 2019; Perttu et al. 2020) or sector collapse (Walter et al. 2019). According to the definition of Scott et al. (2001), a flank collapse is smaller and does not include the summit, whereas a sector collapse is larger and includes the summit. Although the Krakatau collapse included the summit and is therefore a sector collapse according to the definition of Scott et al. (2001), we use the term flank collapse here to be consistent with the GVP reports and the majority of literature on this event to date.

Volcanoes produce seismo-acoustic waves through a variety of processes and are powerful sources of atmospheric infrasound with frequencies from $\sim 0.01$ to $20 \mathrm{~Hz}$ (Johnson et al. 2004; Fee and Matoza 2013; Matoza et al. 2019). Infrasound can propagate for thousands of kilometers in atmospheric ducts between Earth's surface and upper atmosphere, enabling long-range infrasound signal detection (Liszka 1974; Georges and Beasley 1977; Sutherland and Bass 2004; Campus and Christie 2010; Christie and Campus
2013). The bathymetry map was created using the ETOPO1 1 ArcMinute Global Relief Model (Amante \& Eakins, 2009). The inset satellite map uses a visual-band image from the Sentinel-2 satellite, taken at the start of the new eruptive phase on June 19, 2018 (modified Copernicus Sentinel Data 2019). IMS: International Monitoring System

2010). Infrasound technology has emerged in recent years as a useful tool to detect and locate volcanic eruptions at local to remote distances (Dabrowa et al. 2011; Matoza et al. 2011a, 2017, 2019). Similarly, hydroacoustic signals can propagate for thousands of kilometers with low attenuation in the ocean water column especially in the Sound Fixing and Ranging (SOFAR) channel waveguide (Ewing and Worzel 1948; Johnson and Norris 1968; Talandier and Okal 2001). The SOFAR waveguide allows hydroacoustic propagation exclusively by refraction, with minimal signal power loss through reflections at the sea surface or seafloor (Jensen et al. 2011). Hydroacoustic signals from a volcanic eruption were first detected in 1952 (submarine Myojin volcano; Dietz and Sheehy 1954), and other volcanic eruptions have been detected at hydrophone stations up to $\sim 15,800 \mathrm{~km}$ from the volcanic source (Metz et al. 2016). This remote hydroacoustic and infrasonic detectability has the potential to aid substantially in volcanic hazard monitoring, as explosive eruptions at remote subaerial, submarine, and partially submerged volcanoes can pose numerous hazards to local 
populations, shipping, and aircraft (Przedpelski and Casadevall 1991; Spence et al. 2005; Masson et al. 2006; Schneider et al. 2020).

We present analyses using data from infrasonic and hydroacoustic stations of the global International Monitoring System (IMS). The IMS network was constructed as a component of the verification regime of the Comprehensive Nuclear-Test-Ban Treaty (CTBT) to detect explosions anywhere on Earth (Marty 2019). Infrasonic and hydroacoustic stations of the IMS have been used to characterize and provide chronologies of eruptions, both subaerial (e.g., Dabrowa et al. 2011; Fee et al. 2010; Matoza et al. 2011a, 2018) and submarine (e.g., Green et al. 2013; Metz et al. 2016; Tepp et al. 2019).

Here we compile infrasound and hydroacoustic data from the start of the new eruptive phase at Anak Krakatau in June 2018 through the end of the Surtseyan eruption in January 2019 and place these signals in context with the eruption chronology. We investigate infrasound and hydroacoustic signals from 7 months prior to the December 2018 flank collapse, as well as the flank collapse event and subsequent Surtseyan activity, to provide a longer temporal context for these observations in complement to recent publications on this event (Grilli et al. 2019; Williams et al. 2019; Walter et al. 2019; Paris et al. 2020; Perttu et al. 2020; Ye et al. 2020).

\section{Eruptive history}

The Krakatau volcanic complex is the result of arc volcanism caused by subduction of the Australian plate beneath the Sunda plate, and crustal thinning caused by the extensional faulting and rifting of the Sunda Strait (Dahren et al. 2011). The 1883 eruption culminated in a sequence of large magmatically driven explosions that generated catastrophic pyroclastic flows and a tsunami in the Sunda Strait (Self and Rampino 1981), which are estimated to have killed over 36,000 people (Auker et al. 2013). The 1883 tsunami mechanism is uncertain; pyroclastic flows entering the ocean (Self and Rampino 1981) or violent submarine explosions (Yokoyama 1981) have been proposed as the source. The eruption destroyed most of the volcanic edifice, forming a partially submarine caldera. Anak Krakatau began forming as a cone on the northeast rim of the caldera during an eruption in 1927, emerging above sea level in 1928 (Stehn 1929). The volcano has erupted frequently, with at least 40 recorded episodes of Strombolian to Vulcanian style eruptive activity characterized by ash plumes, explosions, incandescent ejecta, and lava flows (Global Volcanism Program 2019). A submarine eruption on the volcano's south flank was observed by eyewitnesses on April 11, 1972 (Global Volcanism Program 1972), and lava domes were reported in 2011, 2012, and 2017 (Global Volcanism Program 2011,
2012 , 2017). Since 1928, the volcano has been growing predominantly toward the southwest, toward the center of the 1883 caldera (Deplus et al. 1995), making the southwest part of the edifice particularly unstable. By October 2018, the cone of Anak Krakatau had grown to a height of $338 \mathrm{~m}$ above sea level (Global Volcanism Program 2019).

\section{New eruptive phase chronology}

After a 15-month period of quiescence, a new eruptive phase began on June 18, 2018, characterized by an increase in seismic activity (Global Volcanism Program 2018). Ash plumes and explosions from the volcano were first observed on June 21, 2018, followed by the first incandescence on July 1, 2018 (Global Volcanism Program 2018). Lava flows reached the sea on September 22, 2018, and frequent explosions, ash plumes, and incandescent material were observed from July through December of 2018. On December 22, 2018, a period of intense Strombolian activity began, characterized by explosions, lava fountaining, ballistics, and a sustained ash column. At 13:55 UTC, the southwest side and summit of the volcano collapsed into the ocean resulting in a tsunami which impacted the coastlines of Banten and Lampung (Walter et al. 2019; Perttu et al. 2020). The tsunami was first detected on tide gauges at 14:28 UTC and traveled up to $330 \mathrm{~m}$ inland with a maximum surveyed runup of $13.5 \mathrm{~m}$, resulting in 437 deaths and $>30,000$ injuries (Muhari et al. 2019). Estimates by Ye et al. (2020) indicate that the flank collapse slide volume was small $\left(<\sim 0.2 \mathrm{~km}^{3}\right)$ and did not produce short-period seismic waves strong enough to trigger a warning from the existing Indonesian tsunami warning system. As a result of the flank collapse, the vent was submerged in seawater, and eruptive activity transitioned to sustained Surtseyan activity. This Surtseyan activity, base surges, and a sustained ash plume were observed from December 23, 2018 through January 9, 2019, when a rim of tephra formed around the vent, forming a crater lake (Global Volcanism Program 2019). The eruption has continued to the time of writing (April 2021).

\section{Observations}

\section{Data}

We search infrasound data from the three closest IMS infrasound stations to Anak Krakatau for volcanic eruption signals: IS06 (Cocos Islands; 1,156 km), IS07 (Warramunga, Western Australia; 3,475 km), and IS52 (Chagos Archipelago, British Indian Ocean Territory; 3,638 km) (Fig. 1). IS06 and IS07 are 8-element arrays, station IS52 is a 7-element array. Each station has a total $\sim 1-2 \mathrm{~km}$ aperture across array elements, spatial pipe filters on each array element (sensor) 
to reduce wind noise, and a sampling frequency of $20 \mathrm{~Hz}$ (Marty 2019).

We also analyze hydroacoustic data from two Indian Ocean IMS hydrophone stations: H08 (Chagos Archipelago; $3307 \mathrm{~km}$ ) and H01W (Cape Leeuwin, Western Australia; $3720 \mathrm{~km}$ ) (Fig. 1). H08 is constructed of 2 triplet arrays, but only the southern triplet (H08S) is used here due to lack of data availability for the northern triplet $(\mathrm{H} 08 \mathrm{~N})$ at the Incorporated Research Institutions for Seismology Data Management Center (IRIS DMC). H01W consists of one triplet array. The triplets at each station are moored at the approximate depth of the SOFAR channel at each location ( $\sim 1 \mathrm{~km}$ average depth at $\mathrm{H} 01 \mathrm{~W}$, and $\sim 1.4 \mathrm{~km}$ average depth at $\mathrm{H} 08 \mathrm{~S}$ ) to intercept long-distance hydroacoustic signals, with a horizontal sensor spacing of $\sim 2 \mathrm{~km}$ and a sampling rate of $250 \mathrm{~Hz}$ (Lawrence 2004).
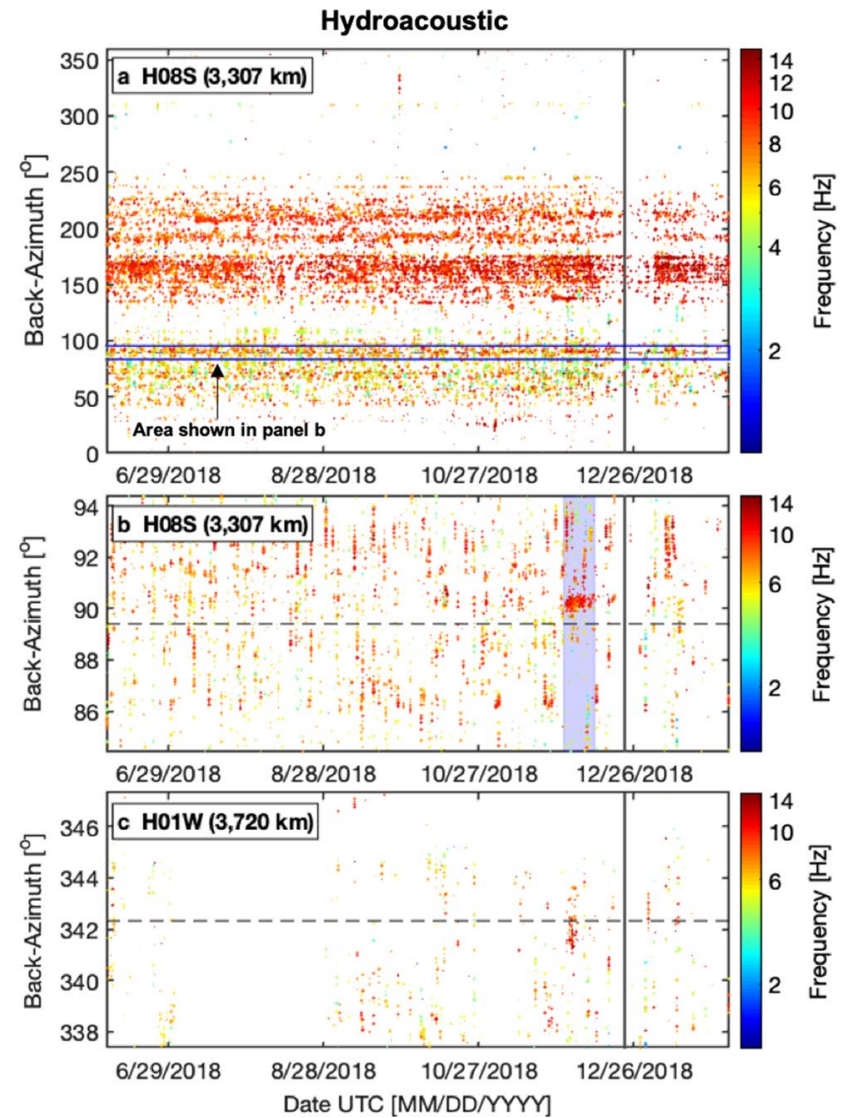

Fig. 2 PMCC summary detections for infrasound and hydroacoustic stations from June 5, 2018, to January 31, 2019. Horizontal dashed black lines indicate the back-azimuth of Anak Krakatau, and vertical solid black lines indicate the major flank collapse event on December 22, 2018 at 13:55 UTC. Blue-outlined region in a shows the extent of $\mathbf{b}$. The blue-shaded region in $\mathbf{b}$ shows the length of the hydroacoustic swarm at H08S with a similar back-azimuth to Krakatau. The blue shaded regions of H08S and IS06 indicate the signal timeframes from which hydroacoustic and infrasound events were picked to investigate waveform similarity in Figs. 8 and 9. c The H01W plot shows detections that overlap with the H08S swarm. d IS06, the clos-

\section{Array processing}

We perform array processing for infrasound and hydroacoustic data from June 5, 2018, through January 31, 2019 (Fig. 2) using the Progressive Multi-Channel Correlation (PMCC) method (Cansi 1995; Le Pichon et al. 2010), which uses time-domain correlation to measure signal delays between array elements, detect coherent signals, and estimate wavefront parameters (backazimuth, apparent velocity) for a set of filter bandpasses. The PMCC algorithm identifies coherent acoustic signals propagating across subsets of 3 sensors (triplet subarrays) in the array, and consistency in estimated wavefront parameters between progressive subarrays results in a detection logged as a "pixel" (a correlated
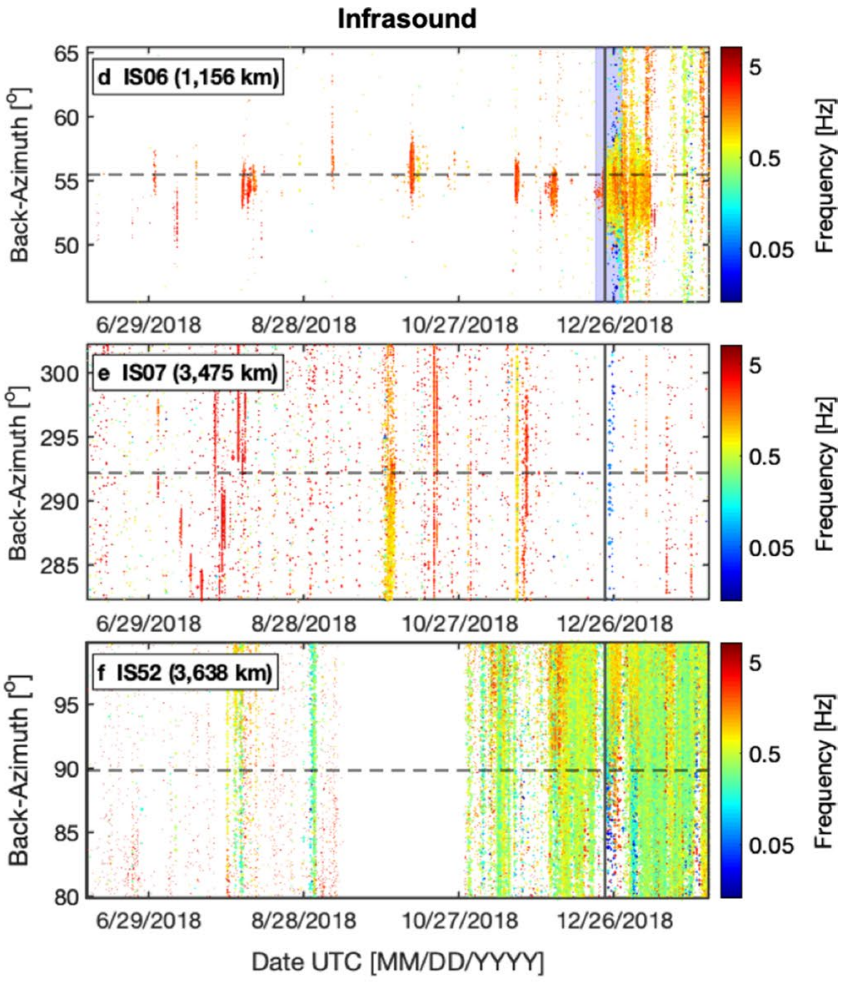

est IMS station, shows intermittent signal arriving from the back-azimuth direction of Anak Krakatau from July to December, 2018 (see Fig. 3 for detail), followed by powerful detections during the main eruption sequence from December 22, 2018, to January 9, 2019, with the end of Surtseyan activity. e IS07 does not show continuous detections from the direction of the volcano. $\mathbf{f}$ The detections at IS52 are dominated by microbarom clutter (e.g., Matoza et al. 2011b, 2013; Williams et al. 2020), but magnifying the plot to the time of the main eruption reveals co-eruptive signal beneath the clutter (see Fig. 4). PMCC: Progressive Multi-Channel Correlation; IMS: International Monitoring System 
acoustic signal in a particular time-window and frequency band pair) (Cansi and Klinger 1997). Pixels with similar wavefront characteristics are grouped into pixel "families." The PMCC method is the signal detector in use for infrasound array data processing by the International Data Center (IDC) of the Comprehensive Nuclear-Test-Ban Treaty Organization (CTBTO), and a similar but different method (DFX-HASE, or Hydroacoustic Azimuth and Slowness Estimator) has been used for IDC hydroacoustic data processing (Mialle et al. 2019). Therefore, in preliminary work, we tested the PMCC method using published eruption case studies (2010 South Sarigan; Green et al. 2013) to calibrate the PMCC parameter selection for IMS hydroacoustic array data (Rose 2020). We demonstrate the effectiveness of a log-frequency band implementation of PMCC for hydroacoustic data processing, consistent with work by Vergoz and Millet (2019) and Vergoz et al. (2019). For the infrasound station PMCC processing, we used 15 frequency bands log-spaced from 0.01 to $9.9 \mathrm{~Hz}$ corresponding to window lengths ranging from 30 to $200 \mathrm{~s}$ (Matoza et al. 2013), and for the hydroacoustic stations, we used 40 frequency bands log-spaced from 0.01 to $120 \mathrm{~Hz}$ with window lengths ranging from 30 to $400 \mathrm{~s}$.

\section{Infrasound}

The closest infrasound station IS06 recorded intermittent infrasound from July 2018 to December 2018 arriving from the back-azimuth of Anak Krakatau (i.e., in the months before the flank collapse event) (Fig. 3). These infrasound detections have an overall mean frequency of $2.7 \mathrm{~Hz}$ (mean refers to average values for pixels in a family), with pulses of activity lasting from hours up to $\sim 3$ days each, separated by periods of quiescence. On December 18-22, 2018, station IS06 recorded intermittent detections from Anak Krakatau with a mean frequency of $2.1 \mathrm{~Hz}$, which became continuous at 06:43 UTC on December 22, 2018, and marked the start of powerful Strombolian style eruptive activity.

Beginning December 22, 2018, IS06 records 19 days of powerful, nearly continuous infrasound associated with the main
Fig. 3 Station IS06 infrasound detections of eruptive activity leading up to, during, and after the flank collapse and tsunami at Anak Krakatau. a PMCC summary detections for infrasound activity from June 3 , 2018, through January 31, 2019. At least 8 sequences of eruptive activity are recorded before the main eruption with flank collapse begins (black arrow). Two example sequences of eruptive infrasound in the months prior to the flank collapse are selected with blue dashed rectangles and detailed in the lower panels. b PMCC detections, the waveform, and spectrogram activity for a sequence of activity from August 3-11, 2018. c The same for activity from October 7-11, 2018. The waveforms were time-delay beamformed and high-pass filtered above $0.7 \mathrm{~Hz}$ to remove microbarom noise, and the spectrograms were beamformed. The horizontal black-dashed lines on each PMCC detection plot show the back-azimuth direction of Anak Krakatau, and the solid red circles behind the waveforms indicate times of PMCC bulletin (summary) detections that were within $\pm 3^{\circ}$ of the volcano backazimuth. PMCC: Progressive Multi-Channel Correlation

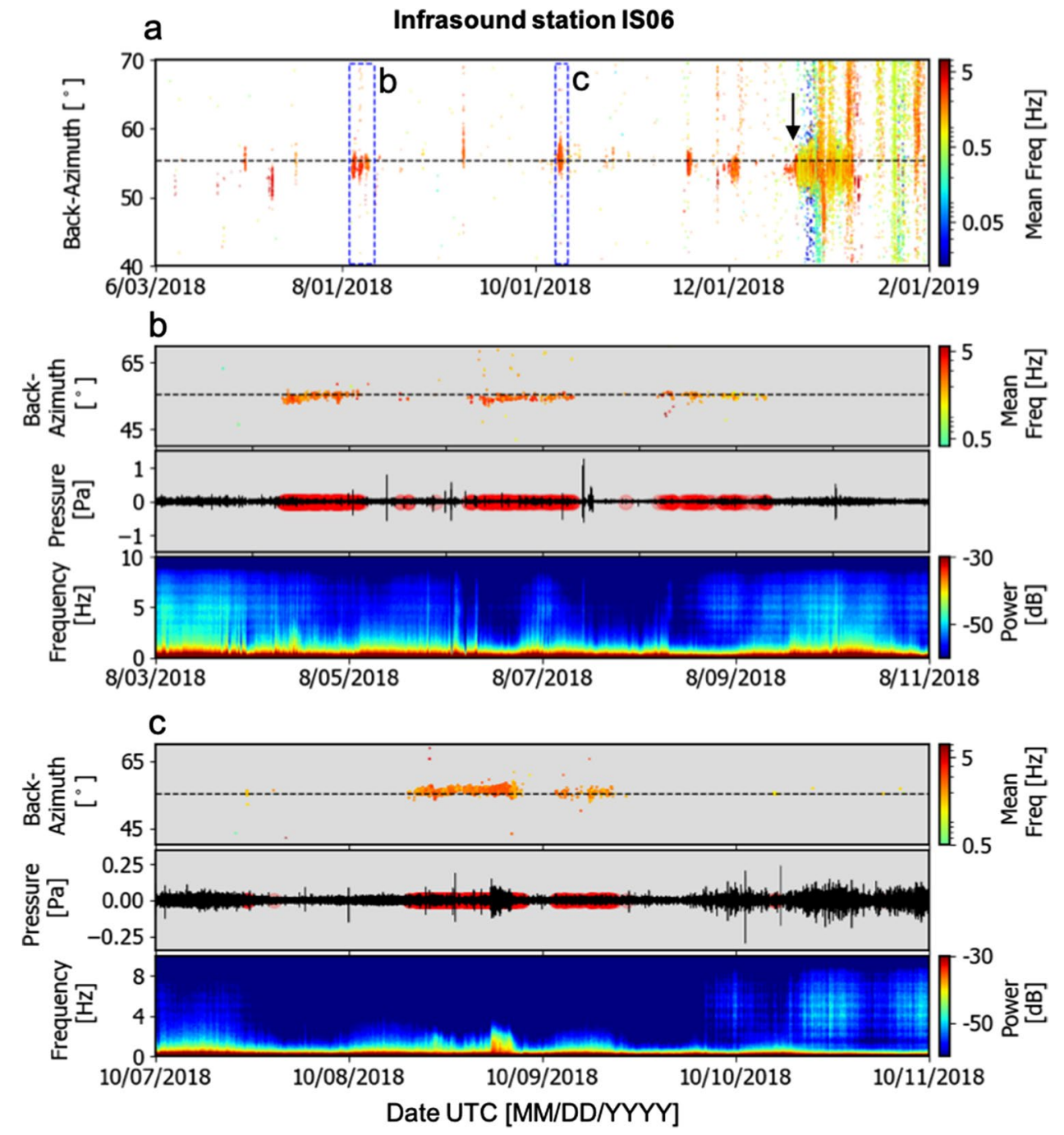

Infrasound station IS06 


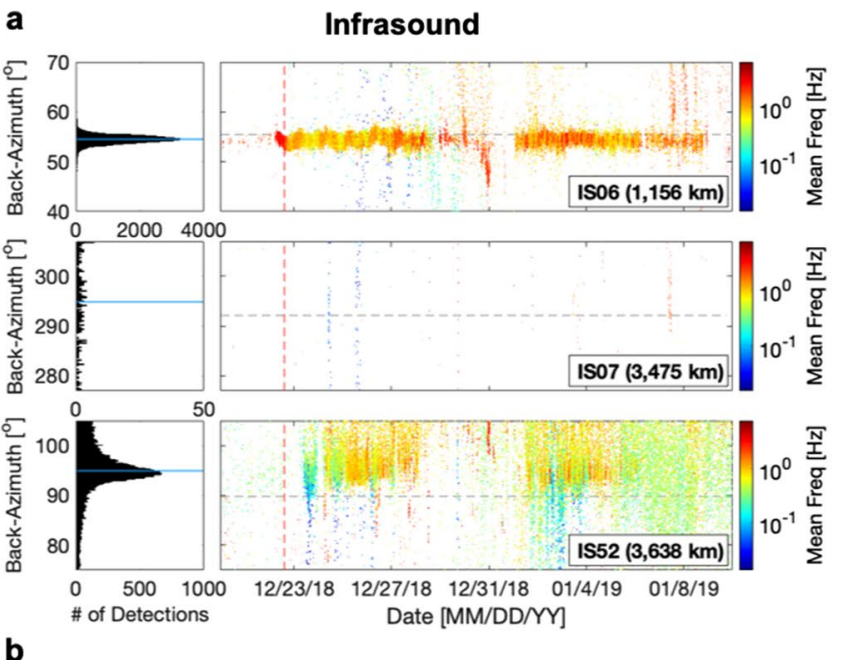

b

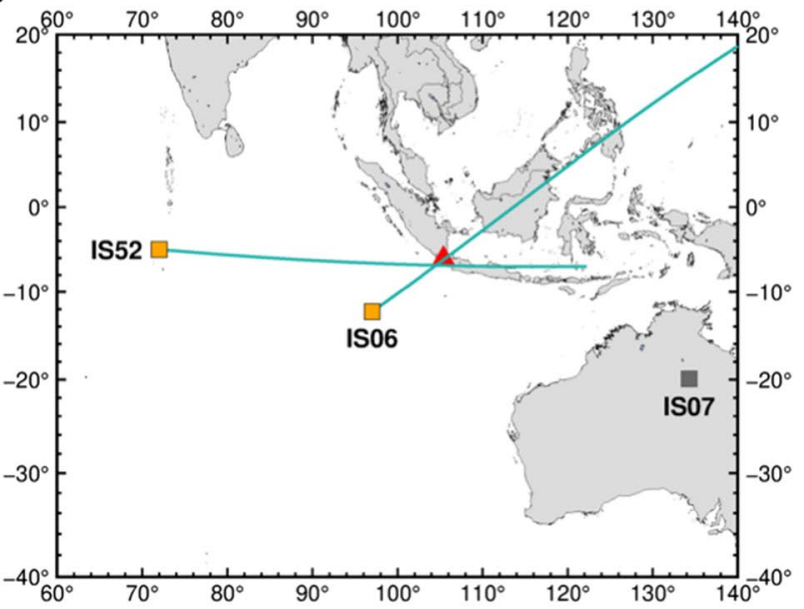

Fig. 4 a Comparison of PMCC summary infrasound detections. The back-azimuth of Anak Krakatau is indicated on each panel with a gray dashed line, and the time of the flank collapse at 13:55 on December 22, 2018, is indicated by a vertical red-dashed line. Eruptive activity at Anak Krakatau is detected infrasonically at IS06 and IS52. Krakatau detections at IS52 are partially obscured by microbarom clutter, but the histogram of detections for the time range of the plot shows a significant peak in detections near the direction of the volcano. Blue lines on the histograms indicate the median backazimuth of all detections in each panel. b Detection cross-bearings for infrasound stations IS06 and IS52 where coherent eruptive detections are observed, calculated using the median back-azimuth of detections at each station during the eruption period. The great circle paths at
C

Hydroacoustic

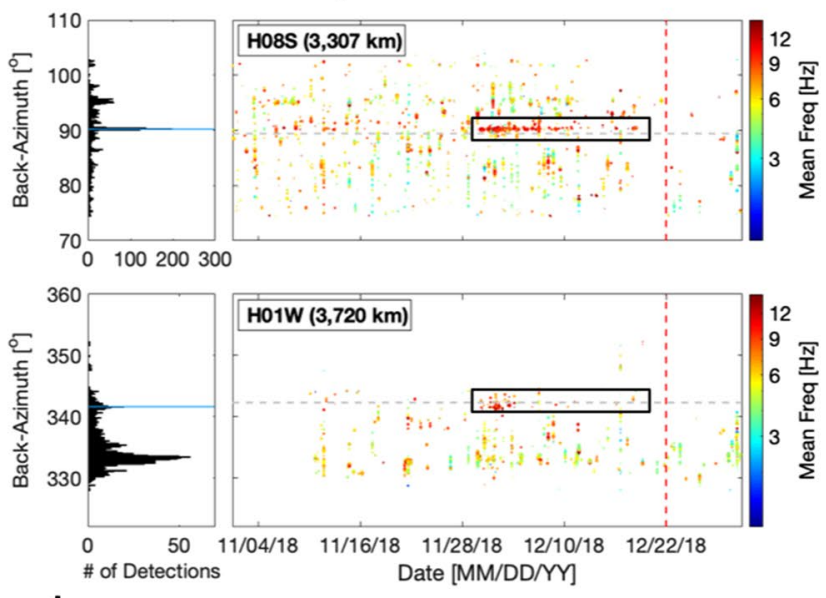

d

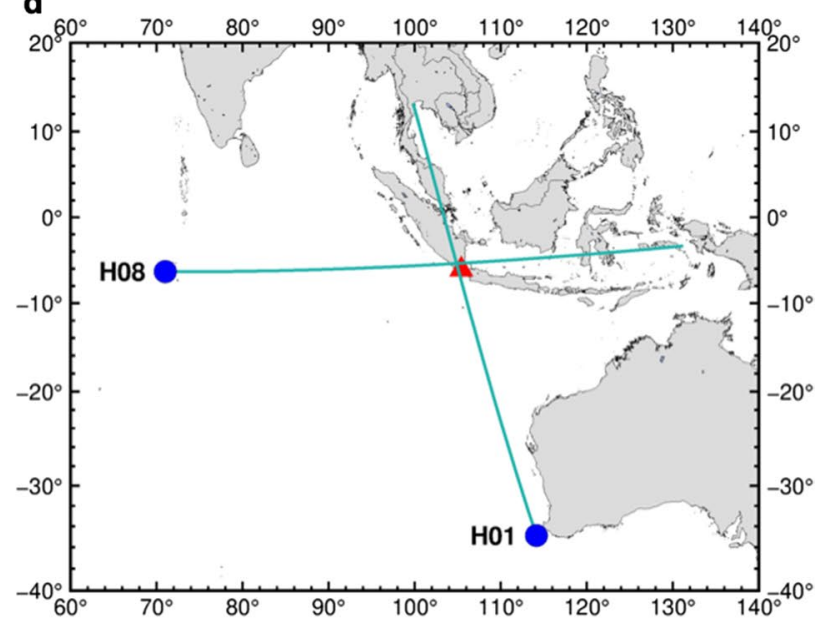

the median back-azimuth directions are indicated with solid teal lines. Anak Krakatau is indicated by a red triangle. The back-azimuth intersection of the cross-bearings is $128 \mathrm{~km}$ from true. c Comparison of PMCC summary hydroacoustic detections, parsing only detections with mean frequencies of $1-15 \mathrm{~Hz}$ to reduce ocean clutter (background hydroacoustic signals). The main eruption and flank collapse were not detected hydroacoustically, but H08S and H01W detect a 12-day hydroacoustic swarm ending 12 days before the main eruption began. Blue lines on the histograms indicate median back-azimuth of detections of suspected volcanic activity (black rectangle). d Detection cross-bearings for $\mathrm{H} 08 \mathrm{~S}$ and $\mathrm{H} 01 \mathrm{~W}$ hydroacoustic swarm. The back-azimuth intersection of the cross-bearings is $100 \mathrm{~km}$ from true. PMCC: Progressive Multi-Channel Correlation eruption phase (intense Strombolian activity followed by the flank collapse, tsunamis, and the onset of Surtseyan activity; Fig. 4). The waveform and spectrograms presented are for a time-delay beamformer implemented by Matoza et al. (2007), which is used to delay and stack the signals from the elements of the array and reduce incoherent noise. Using PMCC bulletin (i.e., summary) detections at IS06, we identify a period of weak, higher-frequency ( $3.0 \mathrm{~Hz}$ average) activity at Anak Krakatau lasting for $\sim 89 \mathrm{~h}$, followed by the onset of high-amplitude Strombolian activity on December 22, 2018, beginning at 05:17 UTC, which increased in intensity until 07:41 UTC (Figs. 4 and 5). The flank collapse occurred at $\sim 13: 55$ UTC (Walter et al. 2019; Perttu et al. 2020), and was recorded at station IS06 (Fig. 5). The flank collapse signal lasts $\sim 6 \mathrm{~min}$ and appears on the beamformed spectrogram as three $\sim 2 \mathrm{~min}$ duration higher frequency pulses with frequency content in the $0.1-4 \mathrm{~Hz}$ range. The first and third pulses are of lower amplitude, but the middle pulse is a powerful 70-s duration, highamplitude (4.5 Pa) signal. The detail of the flank collapse waveform is shown on Fig. 5c. 

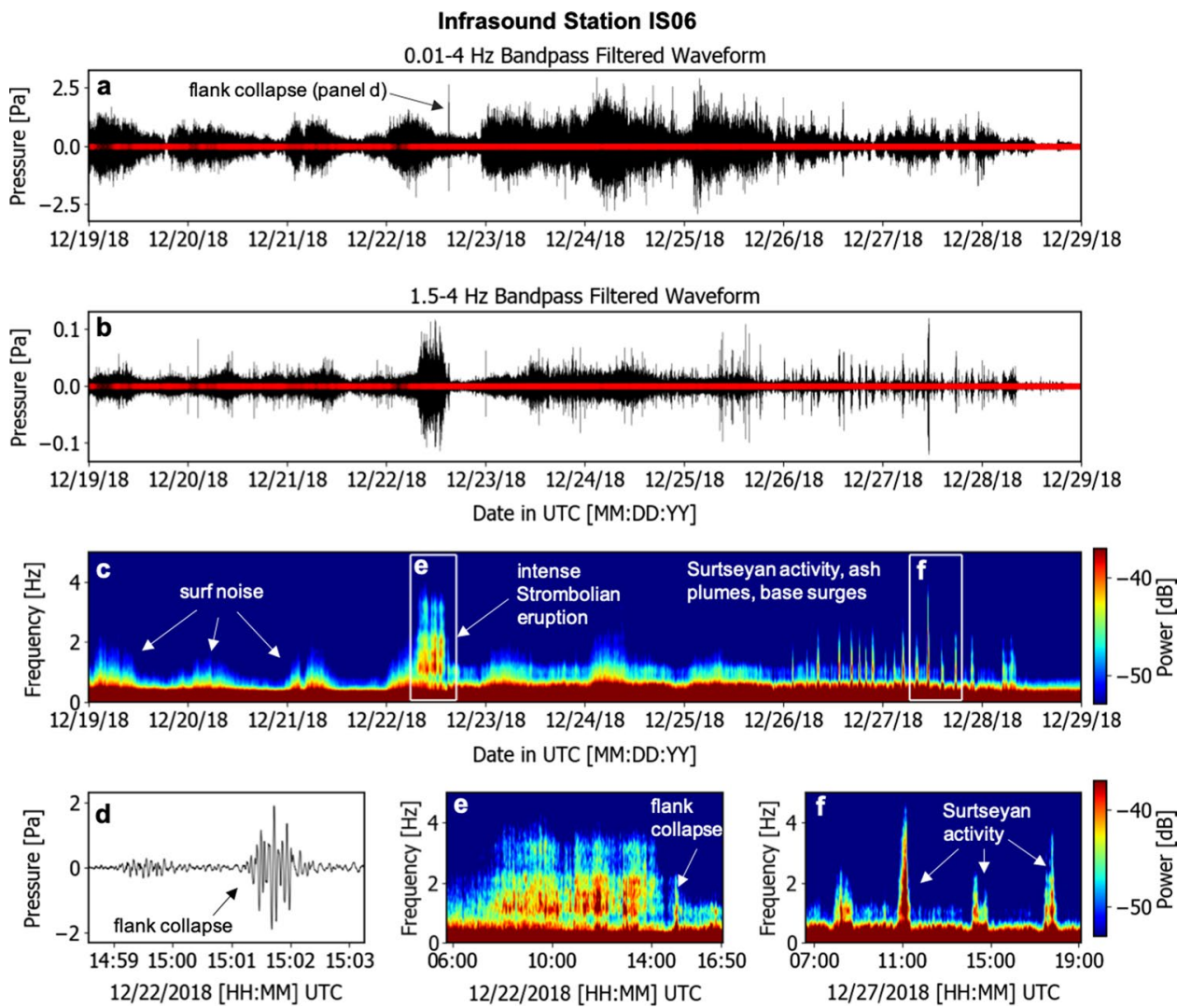

Fig. 5 Infrasound station IS06, Cocos Islands (1156 km range) waveforms and spectrograms for a 10-day period, from December 19-29, 2018, including the beginning of the climactic eruption phase and flank collapse on December 22, 2018, followed by signals from December 22-29, 2018, that we attribute to Surtseyan activity, base surges, and ash plumes based on eyewitness observations at the volcano reported by the Smithsonian's Global Volcanism Program (2019). Panel a shows the 0.01-4 Hz bandpass filtered and beamformed waveform, and panel b shows the $1.5-4 \mathrm{~Hz}$ bandpass filtered and beamformed waveform. Solid red circles indicate when

Immediately after the flank collapse, we observe an overall drop in frequency content. The average frequency of PMCC summary detections from the time of the flank collapse until the end of Surtseyan activity on January 9, 2019, is $1.3 \mathrm{~Hz}$, though detections fluctuate between periods of higher and lower frequencies.

Though microbarom "clutter" (correlated signals other than the signals of interest; Landès et al. 2012; Matoza et al. 2013) dominates the detections at IS52, a notable increase in the number of detections arriving from the back-azimuth of Anak Krakatau shows that IS52 captured sustained infrasound from the main eruption sequence (Fig. 4). A band of detections with stable back-azimuth and mean frequency of $0.86 \mathrm{~Hz}$ is present within this clutter that arrives from $\sim 5^{\circ}$ clockwise of the true back-azimuth of the volcano, which we interpret as a volcanic signal with a typical azimuth deviation caused by atmospheric coherent eruptive signal was detected by PMCC as arriving from $\pm 3^{\circ}$ of the Anak Krakatau back-azimuth. Panel c shows the beamformed spectrogram for the 10-day timespan. Panel d shows the detail of the flank collapse signal, bandpass filtered from 0.1 to $4 \mathrm{~Hz}$. Panels e and f show spectral details for the high-power signals from pre-collapse eruption and flank collapse, and the Surtseyan activity, respectively. We observe a notch in the frequency spectrum from $\sim 0.7-1.0 \mathrm{~Hz}$ at IS06, particularly during the intense pre-collapse Strombolian eruption (panel e). PMCC: Progressive Multi-Channel Correlation

cross-wind effects. Detections from both IS06 and IS52 record intermittent higher frequency $(0.5-5 \mathrm{~Hz})$ pulses during the Surtseyan eruption period. The first infrasound attributed to Anak Krakatau at IS52 is recorded $\sim 26 \mathrm{~h}$ after the start of intense Strombolian activity, a delay likely caused by low signal-to-noise ratio (SNR) at IS52 (compare with Fig. 4 of Matoza et al. 2018).

Station IS07 did not record continuous, coherent infrasound attributable to Anak Krakatau during the June 2018 to January 2019 period (Figs. 2, 4). Since infrasound propagation is strengthened when atmospheric winds are directed along the same direction as the wave propagation (especially stratospheric winds for long-range infrasound), and inhibited by wind in the opposite direction (de Groot-Hedlin et al. 2010; Mutschlecner and Whitaker 2010), wind conditions presumably precluded the signal reaching station IS07. 


\section{Hydroacoustic}

The hydroacoustic PMCC detections at H08S do not show continuous detections from the direction of Anak Krakatau during the main eruption sequence, possibly due to low SNR caused by interference from a marine seismic survey (Rose 2020). However, detection results show a 12-day swarm of nearly continuous hydroacoustic signal arriving at H08S from the Anak Krakatau back-azimuth beginning 24 days before the flank collapse and tsunami, from November 29 through December 11, 2018 (Figs. 2, 4). This hydroacoustic swarm arrives from a back-azimuth that is densely populated with other short-duration detections (which we interpret as signals from Java Trench earthquake events and anthropogenic noise) but the swarm is distinguishable from these based on its extended duration. Hydroacoustic waveforms and spectrograms corresponding to these detections show discrete, impulsive signals with frequency content of 3-40 Hz (Fig. 6). We also observe consistent hydroacoustic detections at $\mathrm{H} 01 \mathrm{~W}$, from November 30 through December 4, 2018 (Fig. 4), which overlap with the swarm observed at H08S. We compare the swarm at H08S with activity at IS06 on Fig. 7, which shows that the hydroacoustic detections overlap with explosive eruption activity at Anak Krakatau in the weeks prior to the main eruption and flank collapse event.

In addition to interpreted volcanic signals, H08S and H01W detections include strong bands of detections in the respective back-azimuth directions of the southern Indian Ocean (see Fig. 2, panel a). These detections are consistent with iceberg cracking and calving in the southern Indian Ocean found by Evers et al. (2013), which used satellite observations and hydroacoustic data from the same two IMS stations to monitor iceberg breakup.

\section{Waveform and envelope similarity analysis}

Waveform similarity (multiplet) analysis has been used for seismic data at subaerial volcanoes to identify stable lowfrequency earthquake sources (e.g., Green and Neuberg 2006; Matoza and Chouet 2010; Petersen 2007; Stephens and Chouet 2001) and with acoustic data at submarine volcanoes to classify generation mechanisms of hydroacoustic events (Green et al. 2013). Highly repetitive events which exhibit strongly correlated waveforms indicate a repetitive, stable, non-destructive source, with the energy propagating along an almost identical path to reach the sensor. Events for which the waveforms gradually evolve over time reflect a changing source-time function, source geometry, or source location (Stephens and Chouet 2001). We apply a method similar to Green and Neuberg (2006) and Green et al. (2013) to the hydroacoustic signals from Anak Krakatau to investigate waveform and envelope similarity and resolve whether physical eruption processes may be linked to systematic changes in the waveform and envelope shapes produced.
Fig. 6 a, b Hydroacoustic waveform and $\mathbf{c}$ spectrogram of H08S data from November 29, 2018, to December 11, 2018, encompassing 24-12 days before the onset of the climactic eruption and flank collapse. The waveform and spectrogram have been beamformed in the direction of Anak Krakatau. Panel b shows a reduced pressure range from -5 to $5 \mathrm{~Pa}$ to show detail of smaller events. Solid teal circles on the waveforms indicate coherent PMCC detections from the direction of Anak Krakatau, which we interpret as submarine eruption activity. Panels $\mathbf{d}$ and e show that the hydroacoustic events with corresponding PMCC detections tend to be impulsive and band-limited from $\sim 3$ to $<40 \mathrm{~Hz}$. PMCC: Progressive Multi-Channel Correlation
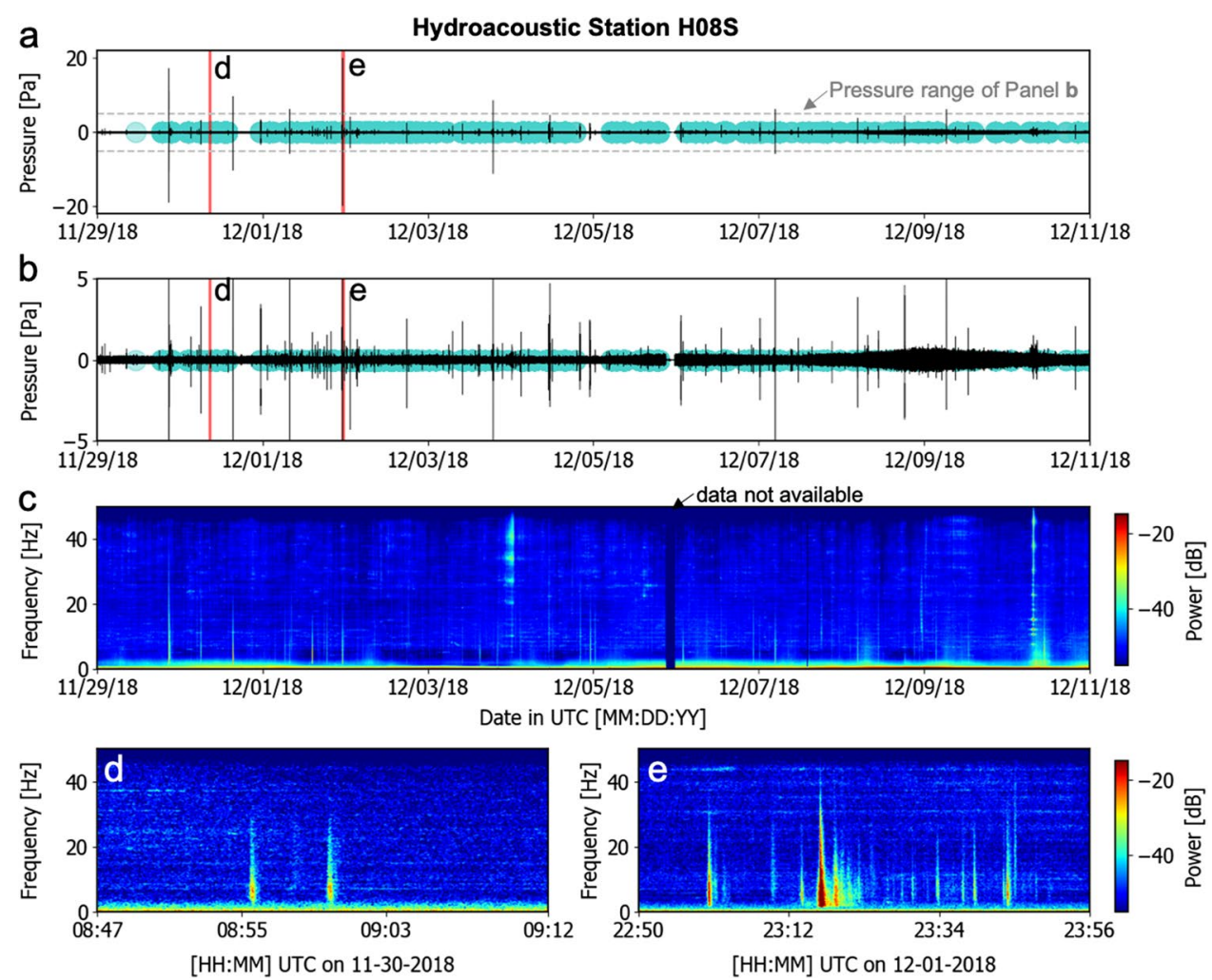

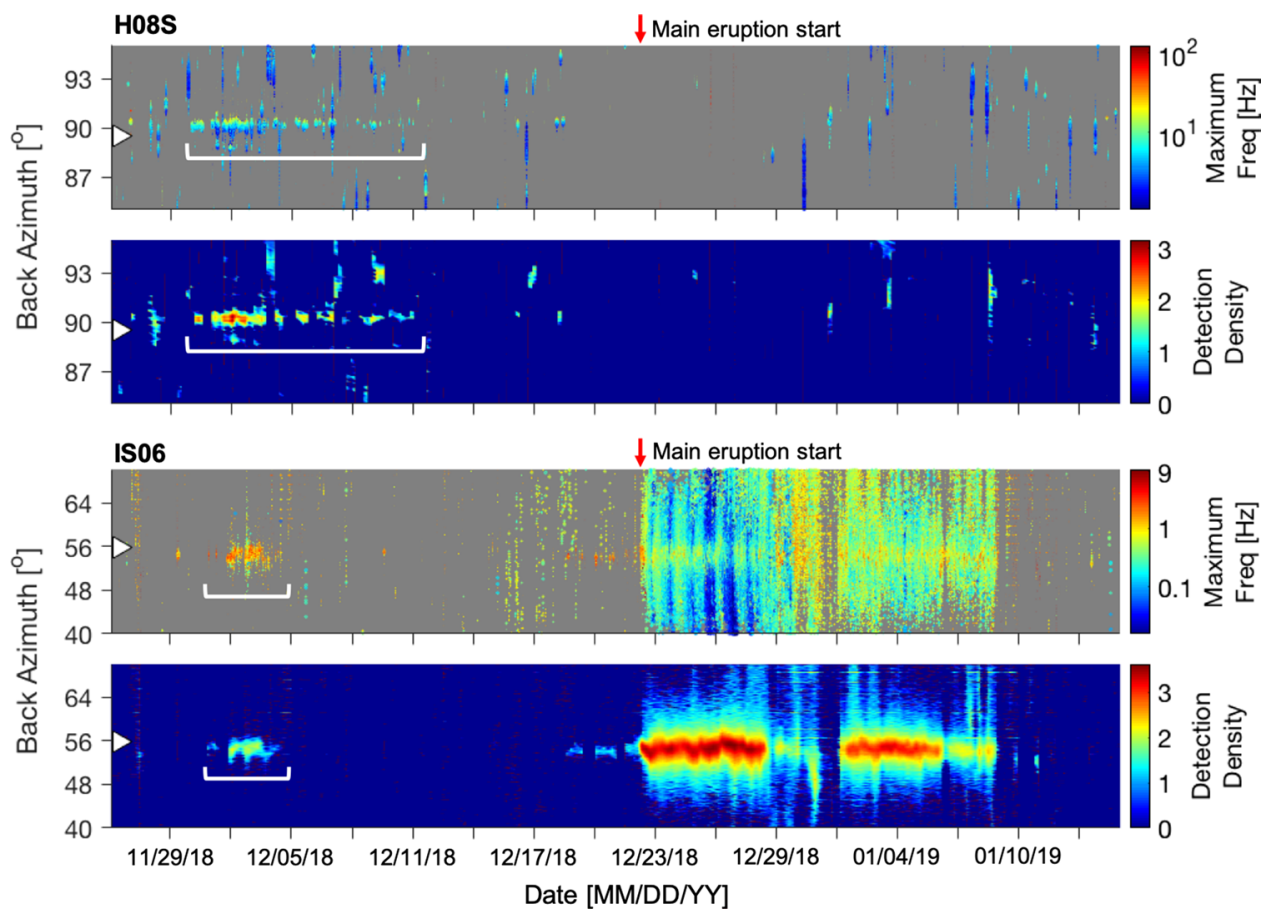

Fig. 7 Scatter plot and 2D histograms of PMCC pixels (that belong to a PMCC family) at hydroacoustic station H08S and infrasound station IS06. Scatter plot (top panel) in each case shows PMCC pixels plotted as backazimuth vs. time and color-coded by frequency. The 2D histogram (lower panel) in each case shows the same backazimuth-time points but grouped into bins of 5-h time increments by $0.1^{\circ}$ backazimuth increments, to show the density of points. H08S shows a hydroacoustic swarm extending from November 29, 2018, to December 13,2018 , but no clear activity during the climactic phase. IS06

\section{Hydroacoustic event similarity}

We first create a starting catalog of hydroacoustic PMCC detections that are likely associated with eruptive activity at Anak Krakatau, without regard for waveform shape similarity. We apply a $2.5-10 \mathrm{~Hz}$ Butterworth bandpass filter to the H08S hydroacoustic data from November 29 to December 11, 2018, and then beamform the signal. The PMCC detections have a minimum 3-s time spacing, and we manually select these detections as "events" except when detections occur continuously, in which case we select every other detection (to avoid correlating the same waveform segments, as we use a $6 \mathrm{~s}$ time window for cross correlation). These detection events are windowed from $1 \mathrm{~s}$ prior to $5 \mathrm{~s}$ after the detection, for a total of 2169 detection events (shown on Fig. 8). We use these picks as input to waveform cross-correlation analysis (Matoza and Chouet 2010). Following Green and Neuberg (2006), Matoza and Chouet (2010), and Green et al. (2013), we calculate event similarity using cross-correlation for each of the hydroacoustic event waveforms with every other event, logging the maximum correlation coefficient into an $m$-by- $m$ matrix, where $m$ is shows infrasound detections from November 30, 2018, to December 5, 2018, partially overlapping the H08S hydroacoustic swarm, followed by a period of quietude until December 18, 2018. This is followed by 5 days of higher-frequency infrasound, and then onset of the main eruption phase and flank collapse on December 22, 2018. This suggests that the eruption involved submarine activity at the same time as infrasound-generating activity was occurring, and which continued for 8 days after the infrasound detections ceased. PMCC: Progressive Multi-Channel Correlation

the number of detection events ( $m=2169$ here). We subsequently attempt to cluster the H08S hydroacoustic events into groups of similar signals (or "multiplets") based on a correlation-coefficient threshold of 0.6 (Green and Neuberg 2006). However, this method resulted in poor correlation of the 2169 detection event waveforms, with only $7.9 \%$ of waveforms correlated above the 0.6 threshold.

Since many of the high-amplitude hydroacoustic events exhibit a longer duration than the 6-s cross-correlation time window, we conduct hydroacoustic signal envelope analysis to determine similarity of the longer signals. This analysis is based on the method of Talandier and Okal (2001), which used hydroacoustic T-phase signal envelopes to distinguish between subduction zone earthquakes, volcanic earthquakes, and explosive submarine events. We made a second set of hydroacoustic picks using only more significant signals with at least 5 successive PMCC detections, for a total of 247 events. Following the waveform cross-correlation method as described above, these events also display poor correlation at the 0.6 threshold $(15.4 \%$ of events correlated above the 0.6 threshold). Therefore, for each event, we bandpass filter from 2 to $15 \mathrm{~Hz}$, beamform, then produce envelopes using a 


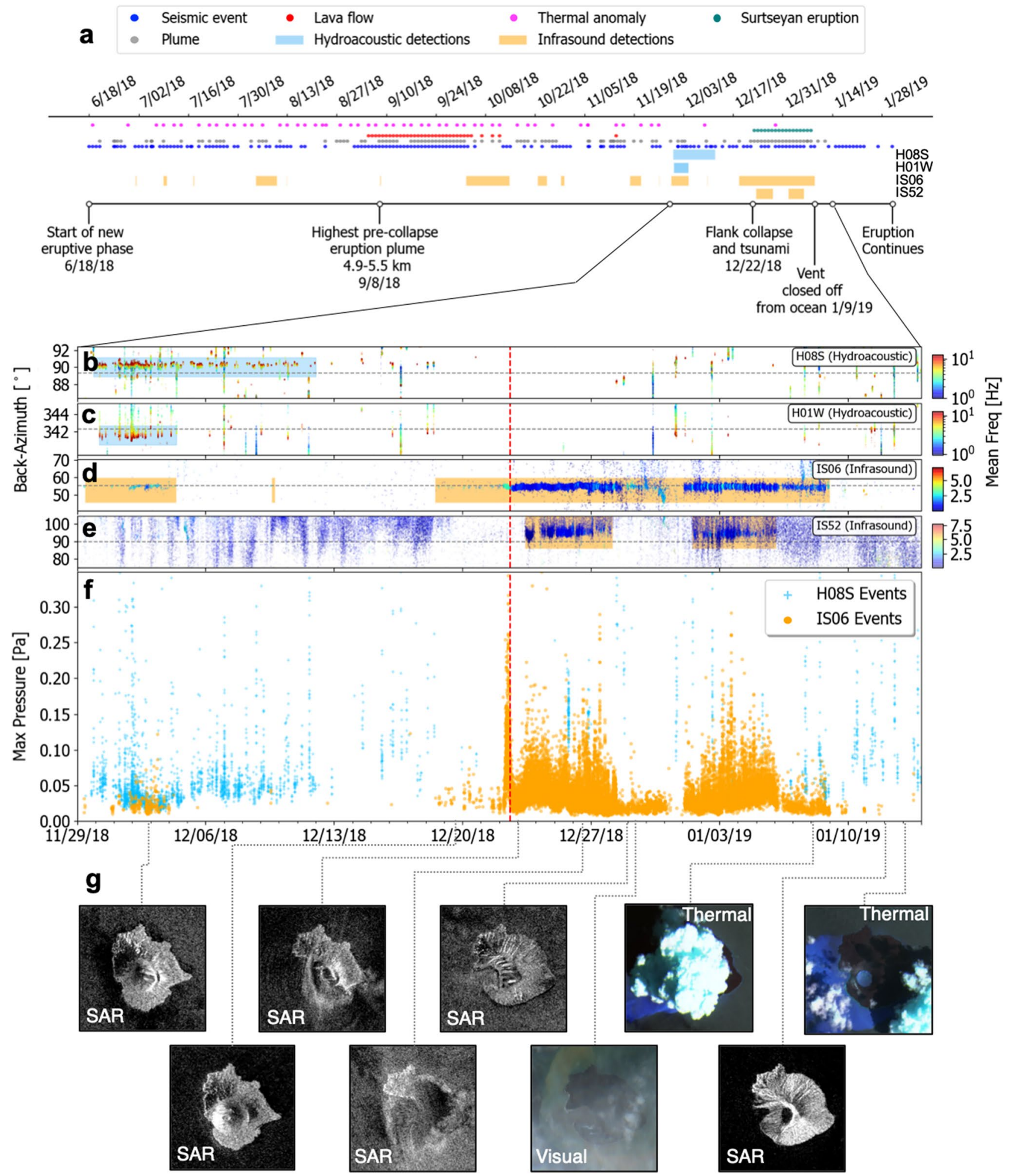

6-s rolling mean. We perform cross-correlation analysis on these envelopes, and of the 247 events, 219 (88.7\%) were correlated above a correlation coefficient threshold of 0.75 . The two largest envelope multiplets are shown on Fig. 9, with 96 waveforms and 101 waveforms, respectively. The two envelope multiplets are qualitatively similar and presumably could be merged, though we do not attempt that here. Minor variations between multiplet 1 and multiplet 2 may be due to variations in source depth, seismo-acoustic coupling location, source location, or source process. 
४Fig. 8 a Timeline of eruption. Magenta circles indicate days with Sentinel-2 satellite thermal anomaly detections (modified Copernicus Sentinel Data 2019), teal circles indicate reported Surtseyan eruption (Global Volcanism Program 2019), red circles indicate days where lava flows were reported (Global Volcanism Program 2019), gray circles indicate days with eruption plumes reported (Global Volcanism Program 2019), and blue circles indicate days on which volcano-seismic events or eruption tremor at Anak Krakatau were reported by PVMBG (Pusat Vulkanologi dan Mitigasi Bencana Geologi 2018). Blue rectangles show the duration of hydroacoustic PMCC detections from H08S and H01W, and orange rectangles show the duration of infrasound detections from IS06 and IS52. b, $\mathbf{c}$ PMCC hydroacoustic pixel detections. d, e PMCC infrasound bulletin (summary) detections. Horizontal dashed black line on panels $\mathbf{b}-\mathbf{e}$ indicates back-azimuth direction of Anak Krakatau, and vertical red-dashed lines indicate the approximate time of the flank collapse which triggered the tsunami. f Infrasound (IS06) and hydroacoustic (H08S) events. Infrasound events were picked using network STA/LTA with PMCC crosschecking method, while hydroacoustic events were picked manually corresponding to PMCC detections. g SAR satellite imagery from Sentinel-1 and thermal and visual satellite imagery from Sentinel-2 showing the effects of the eruption on the morphology of the volcanic edifice (modified Copernicus Sentinel Data 2019). The diameter of the island measured from its most northern to most southern point is approximately $2.2 \mathrm{~km}$. STA/LTA: short-term average/long-term average; PMCC: Progressive Multi-Channel Correlation; PVMBG: Indonesian Centre of Vulcanology and Geological Hazard Mitigation

We compare examples of the volcanic waveforms from December 1, 2018, to other high-amplitude clutter signals, representing PMCC detections from a different direction (not Anak Krakatau) on this day (Fig. 9). The Krakatau waveforms are of shorter duration $(\sim 20 \mathrm{~s})$, with a sharper onset and conclusion than the clutter waveforms. The volcanic envelopes are qualitatively more similar in shape to volcanic earthquake and explosive volcanism envelopes observed by Talandier and Okal (2001) at submarine Lō'ihi volcano, Hawaii, whereas the clutter envelopes are more similar to tectonic earthquake envelopes described in that study.

\section{Discussion}

\section{Intermittent infrasound, July-December 2018}

IS06 is the closest IMS infrasound station to Anak Krakatau and recorded the most robust set of remote acoustic detections linked to this eruption. Intermittent pulses of infrasound were observed at IS06 from July to December 2018 from the back-azimuth of Anak Krakatau (Fig. 3), before the flank collapse and tsunami event. Due to their consistent back-azimuth range over the 6-month period and temporal coincidence with reports of seismic events, eruption plumes, lava flows, or thermal anomalies at the volcano (the occurrences of which are detailed on Fig. 8), we attribute these pulses to periods of subaerial explosive eruption activity at Anak Krakatau. These eruptive pulses were less powerful than the main eruptive phase, but could have contributed to destabilization of the volcanic flank. However, not all instances of the seismic, plume, lava, or thermal events corresponded with co-eruptive infrasound at IS06, indicating a threshold of eruption signal power and atmospheric conditions needed to exceed the noise floor at the station (Green et al. 2013). For example, lava flows were reported from September 5 to October 12, 2018 (Global Volcanism Program 2019), but infrasound attributable to Anak Krakatau was not recorded at IS06 on 24 of these 38 days (Fig. 8). Thus, although lava flows and fountaining can produce locally detectable infrasound (Ulivieri et al. 2013; Gottschämmer et al. 2021), only more energetic explosive activity may produce infrasound powerful enough to be detected remotely.

\section{Hydroacoustic swarm, November 29-December 11, 2018}

The 12-day hydroacoustic swarm observed at H08S is coincident with the last significant pulse in infrasound activity before the onset of the main eruption phase (Fig. 7). Though this swarm overlaps with infrasound detections from November 29 to December 4, 2018, the hydroacoustic events could not be matched with infrasound events by comparing event time delays, indicating a separate source. The presence of this co-eruptive swarm suggests that the eruption produced a period of submarine activity (or earthquakes in the solid Earth coupled to the water column) coincident with subaerial eruptive activity. Due to the limitation of remote data and the challenges of visual observation in a submarine environment, the hydroacoustic source mechanisms are difficult to constrain. Therefore, the discussion presented here is speculative and represents one set of possible interpretations.

The hydroacoustic swarm events from Anak Krakatau are typically confined to the $\sim 3-40 \mathrm{~Hz}$ frequency range, and less than $30 \mathrm{~s}$ duration with minutes to hours between events, suggesting an impulsive rather than sustained source. Impulsive submarine events at other volcanoes have been attributed to underwater phreatomagmatic explosions produced by the opening of a vent (Bohnenstiehl et al. 2013; Tepp et al. 2019), phreatomagmatic explosions as a result of dome building and collapse (Green et al. 2013), bursting magmatic gas bubbles (Chadwick et al. 2008; Dziak et al. 2015), or discrete, shallow volcanic earthquakes coupled into the water column (Dziak and Fox 1999; Dziak et al. 2005; Tepp et al. 2020).

Phreatomagmatic explosions typically have a broadband spectrum (Metz et al. 2016; Tepp et al. 2019), but the $\sim 3-40 \mathrm{~Hz}$ band-limited character of the swarm signals could be a propagation effect. Longer hydroacoustic wavelengths diffract more easily around bathymetric obstructions and would be less attenuated (especially for 

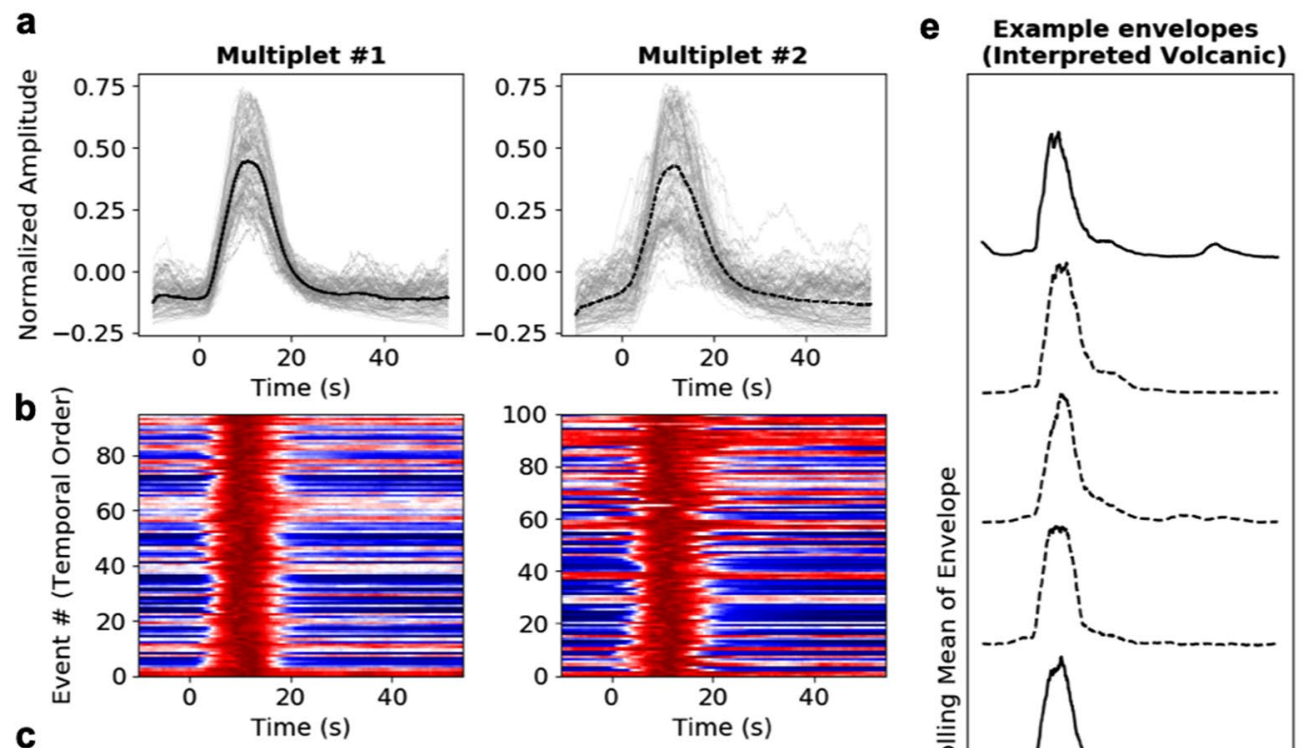

f Example envelopes
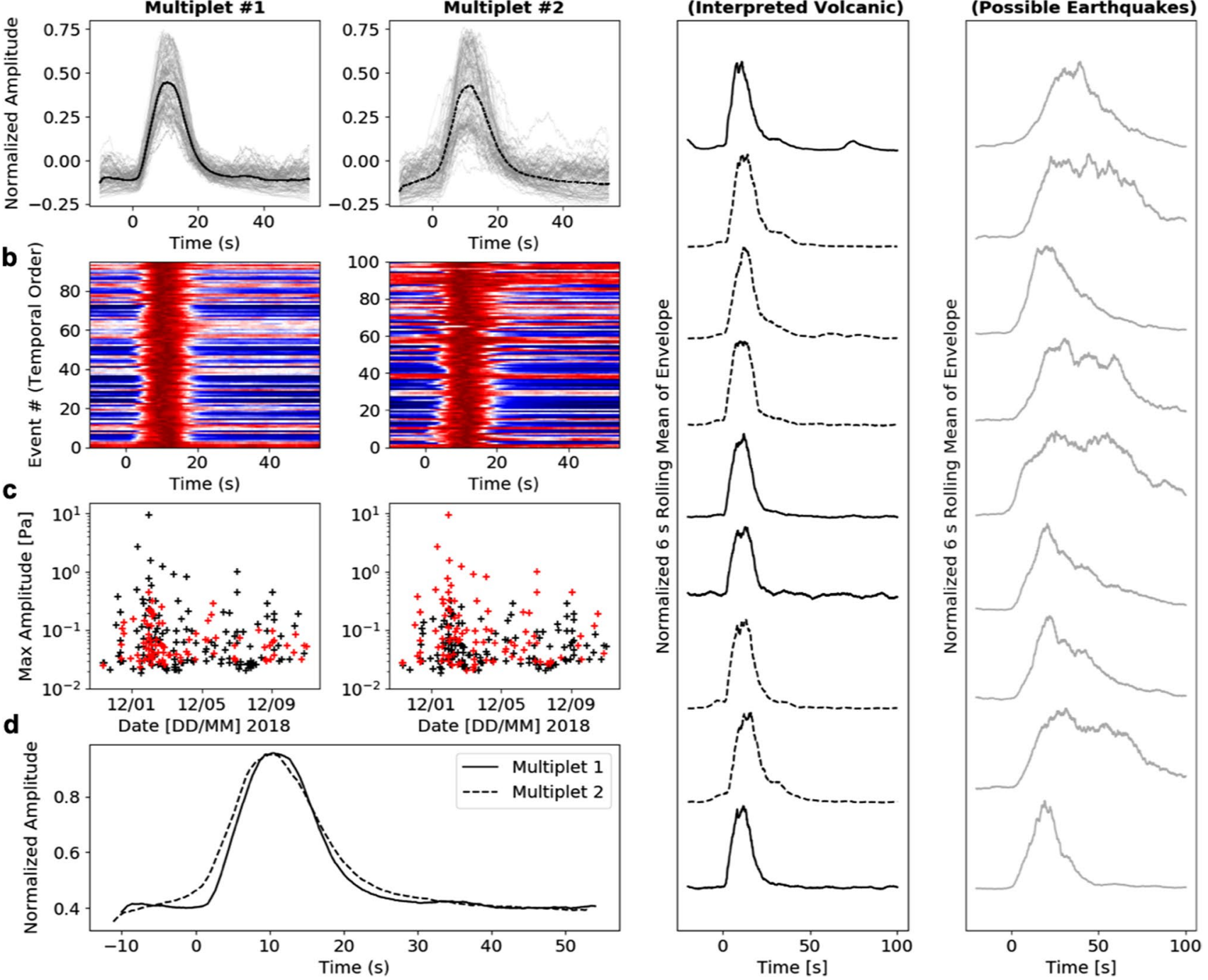

Fig. 9 a The two largest hydroacoustic envelope multiplets at H08S based on a correlation coefficient of 0.75 . Waveforms were filtered from 2-15 Hz, beamformed, normalized, and the $6 \mathrm{~s}$ rolling mean calculated. Individual envelopes of the multiplets are shown in gray, and the master envelope stack of each multiplet in a black solid (multiplet 1) or dashed (multiplet 2) line. b Event matrices for the multiplets in chronological order with the first event at 0 . The events are aligned via cross-correlation to the best-correlated envelope in the multiplet. c The 247 events with greater than 5 PMCC detections as the maximum amplitude of the event with time (black crosses) identifies the events assigned to the multiplet (red crosses). d Comparison of the average envelope of multiplet 1 and multiplet 2, aligned by maximum amplitude. e Example envelopes from December 1, 2018, with PMCC detections from the direction of Anak Krakatau (interpreted as volcanic) and $\mathbf{d}$ clutter envelopes (possible earthquakes). The interpreted volcanic waveforms on $\mathbf{e}$ are solid if they belong to multiplet 1 , and dashed if they belong to multiplet 2 . Multiplet 1 envelopes show a slightly sharper onset and slightly sharper decline than multiplet 2 envelopes, and both multiplets differ significantly from the clutter waveforms, which we interpret as earthquakes based on observations of volcanic vs. tectonic earthquake multiplets in Talandier and Okal (2001)

frequencies of 2-20 Hz. Observations of the 2018 eruption at Ioto volcano off the coast of Japan, another partially submerged volcano, showed similar impulsive hydroacoustic events in the 6-60 Hz range (Matsumoto et al. 2019).

The swarm coincides with reports of seismic events and eruption plumes at Krakatau (Fig. 8), suggesting that the eruption may have been taking place both subaerially and sub-aqueously. Seawater discoloration is a typical 
feature of shallow submarine explosive volcanism (Ossaka 1975; Nogami et al. 1993; Urai and Machida 2005), but Sentinel-2 visual and thermal band satellite imagery was obscured by clouds during this time period, preventing identification of discoloration using this dataset. An alternative explanation is that the hydroacoustic swarm signals represent volcanic earthquakes (in the solid Earth in the region below Krakatau), coupled into the water column from the shallow Sunda Shelf.

The static back-azimuth of these events over 12 days (established by PMCC results) is typical of a volcanic source, and rules out many possible sources of transitory hydroacoustic signal (animal sources, ships, storms, etc.). The minute-to-hour long intervals between successive events and lack of near-perfectly repeating broadband waveforms rule out seismic surveying as the source of the swarm (Rose 2020), and cross-bearing paths of H08S and H01W place the swarm in the vicinity of the Sunda Strait ruling out iceberg or glacier noise (Evers et al. 2013). Though tectonic earthquakes are a major source of hydroacoustic signal in the oceans, the impulsive events of the hydroacoustic swarm occurred over a 12-day period and thus are inconsistent with tectonic earthquake signals which are typically singular events seconds to minutes long (Talandier and Okal 2001). Magmatic gas bubble bursts observed during other submarine eruptions were of much shorter duration ( $<1 \mathrm{~s}$ ) (Dziak et al. 2015) or displayed a characteristic gradual acoustic amplitude buildup and sudden amplitude increase corresponding to the destruction of a solidified lava plug (Chadwick et al. 2008), inconsistent with the results presented here. The intermittent nature of the signal is consistent with a series of explosions over several days as observed during other submarine eruptions, or a swarm of volcanic earthquakes beneath Anak Krakatau coupling efficiently into the water column from the shallow Sunda Shelf. Future work modeling seismo-acoustic coupling and long-range hydroacoustic propagation could further test these hypotheses.

\section{Intense strombolian activity, 06:43-13:55 UTC, December 22, 2018}

The period of intense Strombolian activity reported by eyewitnesses at Anak Krakatau is visible in the IS06 infrasound waveform as a high-amplitude signal and on the spectrogram as a sharp increase in frequency content on December 22, 2018 (Fig. 5). PMCC detections change from low-amplitude intermittent to continuous, high-frequency, high-amplitude detections (Fig. 8). The Sentinel-1 SAR satellite overpass on December 19 before the onset of the main eruption shows the volcanic cone still intact (Fig. 8).
Flank collapse and tsunami, 13:55 UTC, December 22, 2018

The flank collapse signal recorded infrasonically at IS06 exhibits the highest amplitude on the unfiltered, beamformed signal on December 22, 2018, but was not detected at any other IMS stations from which data was analyzed (IS07, IS52, H01W, H08S), consistent with the analysis of Perttu et al. (2020). The tsunami was detected locally by tide gauges in the Sunda Strait (Grilli et al. 2019), and Perttu et al. (2020) report a $\sim 40 \mathrm{~min}, 0.01-0.1 \mathrm{~Hz}$ seismic detection at station IA-CGJI ( $\sim 64 \mathrm{~km}$ from Anak Krakatau) interpreted as the tsunami hitting the coasts of Sumatra and Java.

Submarine volcanic flank collapses and landslides are generally difficult to detect hydroacoustically, especially at long distances. For example, hydroacoustic signal from a 2008 submarine collapse at Monowai volcano was recorded at distances up to $\sim 4270 \mathrm{~km}$, but this signal was interpreted as having been generated mostly by explosive magmaseawater interactions rather than from the collapse itself (Wright et al. 2008). The submarine collapse of NW Rota-1 volcano was recorded hydroacoustically, but only by an insitu hydrophone located $\sim 150 \mathrm{~m}$ from the vent (Chadwick et al. 2012). Arguably, the best record of a submarine landslide recorded hydroacoustically at a remote distance was a landslide from the 1998 Papua New Guinea earthquake, which was recorded at a distance of $3600 \mathrm{~km}$ and had a relatively small spectral amplitude but high-frequency content (Okal 2003).

The interpretation of a lack of signal during the time of the main flank collapse is complicated by background noise for this dataset. The lack of hydroacoustic detection of the main eruption sequence on H08S and H01W coincides with a general decrease in clutter from other sources of hydroacoustic sound such as iceberg cracking and shipping (Fig. 2a). We attribute the decrease in these detections to a powerful interferer (clutter source) consisting of repetitive, broadband pulses, which we interpret as a marine seismic air-gun survey (Rose 2020). These surveys use air-guns to release a quantity of highly pressurized air approximately every 10 to $60 \mathrm{~s}$, resulting in a series of high-amplitude pulses at frequencies of approximately $2-188 \mathrm{~Hz}$ at the source location (Nieukirk et al. 2012). Additional scans through H08S data reveal that these consistent pulses are recorded intermittently at $\mathrm{H} 08 \mathrm{~S}$ from October 28-November 26, 2018, and December 16-27, 2018, including (unfortunately) during the day of the flank collapse and tsunamis, which significantly raises the noise floor during that time. Thus, anthropogenic noise presents a challenge to hydroacoustic detection, as this noise can also propagate efficiently in the ocean waveguide. 


\section{Surtseyan activity, December 22, 2018-January 9, 2019}

Surtseyan activity was reported at Anak Krakatau immediately after the flank collapse and continued until the vent closed off from the ocean on January 9, 2019 (Global Volcanism Program 2019; Fig. 8). The Surtseyan activity was accompanied by a continuous volcanic plume and seismic activity which correspond to the duration of the infrasound detections (Fig. 8a). The PMCC detections of this Surtseyan activity are of lower overall frequency content than the precollapse Strombolian eruption or the intermittent infrasound activity before the onset of the main eruptive phase. We attribute the overall decrease in frequency content to changes in vent morphology and the transition from subaerial Strombolian to Surtseyan activity as the vent was submerged. Coeruptive infrasound (volcanic jet noise) has been observed to decrease as the diameter of the vent increases (Matoza et al. 2009), and a similar frequency decrease was observed at Bogoslof volcano during its 2016-2017 eruption, upon the transition from subaerial to shallow submarine explosive activity (Fee et al. 2020; Lyons et al. 2020). Strong detections continue until January 9, 2019, when they taper off with the conclusion of Surtseyan activity at the submerged vent. Pulses of higher-frequency PMCC detections are visible during the high-amplitude periods of Surtseyan eruption (Fig. 8). We speculate that these frequency changes may be caused by stronger explosions that temporarily cleared the vent, allowing radiation of infrasound directly into the atmosphere resulting in higher frequency content, similar to the vent "drying" observed during the 2016-2017 eruption of Bogoslof volcano (Fee et al. 2020). However, with the available data, we cannot rule out atmospheric propagation effects.

\section{Conclusions}

The eruptive activity leading up to, during, and following the 2018 major flank collapse and tsunami at Anak Krakatau was captured remotely on infrasound and hydroacoustic stations of the IMS global monitoring network (IS06, $1156 \mathrm{~km}$ range; IS52, $3638 \mathrm{~km}$ range; H08S, $3307 \mathrm{~km}$ range; and $\mathrm{H} 01 \mathrm{~W}, 3720 \mathrm{~km}$ range). We have investigated these infrasound and hydroacoustic signals using array processing, waveform and spectrogram analysis, and interpreted possible source processes for observed signals by comparing these with eyewitness reports and satellite imagery. Our analysis complements previous studies of this eruption by placing the catastrophic flank collapse and tsunami in the context of 7 months of prior eruption activity and post-collapse Surtseyan activity. Here we also observe a 12-day hydroacoustic swarm from the direction of Anak Krakatau which coincided with eruption infrasound and which we interpret as submarine eruptive activity which ceased before the onset of the main eruption sequence. The 12-day hydroacoustic swarm may represent volcanic earthquakes coupling to the water column through seismo-acoustic conversion or underwater explosive magma-seawater interactions. Repetitive waveform envelopes with pulse durations of $\sim 20$-s for the hydroacoustic swarm with minor variations suggest repetitive volcanic activity possibly with variations in mechanism and/or location (e.g., changes in earthquake hypocenter and seismo-acoustic coupling location, changes of underwater explosion mechanism source-time-function).

Our results are of utility in the design of future systems to automatically detect submarine volcanism in order to warn ships and aircraft of possible maritime volcanic hazards. Acoustic-based automated detection of intense eruption or flank collapse signals could be added to existing tsunami early warning systems to improve volcanogenic tsunami detection capability, targeting volcanic eruptions as possible tsunami sources in addition to earthquake sources (Strunz et al. 2011). This case study further highlights the role that remote infrasound and hydroacoustic technology can play in the detection and characterization of eruptive activity at submarine and partially submerged volcanoes.

Acknowledgements This work was made possible by the Virtual Data Exploitation Centre (vDEC - https://www.ctbto.org/specials/vdec) platform of the CTBTO that allows access to IMS data for civilian and scientific applications. We thank Gabrielle Tepp, David Green, and editor Bill Chadwick for helpful reviews of the manuscript.

Funding This work was supported by NSF grant EAR-1847736.

Data availability We use data from seismic network code IM (International Monitoring System) downloaded from the IRIS DMC (http:// www.iris.edu). Data from the CTBT IMS infrasound network are also available through the CTBTO vDEC platform (https://www.ctbto.org/ specials/vdec/). Modified Copernicus Sentinel data from the European Space Agency (ESA) is available from Sentinel Hub (https://apps.senti nel-hub.com/eo-browser/).

Code availability The PMCC software (Le Pichon et al. 2010) is developed and maintained by the Commissariat à l'Energie Atomique (CEA). The ObsPy Python toolbox (Beyreuther et al. 2010) is available from www.obspy.org. The GMT toolbox (Wessel and Smith 1991) was used for plotting and is available at https://www.generic-mappi ng-tools.org/.

\section{Declarations}

Competing interests The authors declare no competing interests.

Disclaimer The views presented in this work are those of the authors and do not necessarily represent the views of the CTBTO or any other institution mentioned herein. 
Open Access This article is licensed under a Creative Commons Attribution 4.0 International License, which permits use, sharing, adaptation, distribution and reproduction in any medium or format, as long as you give appropriate credit to the original author(s) and the source, provide a link to the Creative Commons licence, and indicate if changes were made. The images or other third party material in this article are included in the article's Creative Commons licence, unless indicated otherwise in a credit line to the material. If material is not included in the article's Creative Commons licence and your intended use is not permitted by statutory regulation or exceeds the permitted use, you will need to obtain permission directly from the copyright holder. To view a copy of this licence, visit http://creativecommons.org/licenses/by/4.0/.

\section{References}

Amante C, Eakins BW (2009) ETOPO1 1 arc-minute global relief model: procedures, data sources and analysis. NOAA Technical Memorandum NESDIS NGDC-24. https://doi.org/10.7289/ V5C8276M

Auker MR, Sparks RSJ, Siebert L, Crosweller HS, Ewert J (2013) A statistical analysis of the global historical volcanic fatalities record. J Appl Volcanol 2(1):1-24. https://doi.org/10.1186/2191-5040-2-2

Beyreuther M, Barsch R, Krischer L, Megies T, Behr Y, Wassermann J (2010) ObsPy: a python toolbox for seismology. Seismol Res Lett 83(3):530-533

Bohnenstiehl DR, Dziak RP, Matsumoto H, Lau T-KA (2013) Underwater acoustic records from the March 2009 eruption of Hunga Ha'apaiHunga Tonga volcano in the Kingdom of Tonga. J Volcanol Geotherm Res 249:12-24. https://doi.org/10.1016/j.jvolgeores.2012.08.014

Campus P, Christie DR (2010) Worldwide observations of infrasonic waves. In Infrasound Monitoring for Atmospheric Studies (pp. 185234). Springer Science + Business Media. https://doi.org/10.1007/ 978-1-4020-9508-5

Camus G, Gourgaud A, Vincent PM (1987) Petrologic evolution of Krakatau (Indonesia): implications for a future activity. J Volcanol Geotherm Res 33(4):299-316. https://doi.org/10.1016/0377-0273(87)90020-5

Cansi Y (1995) An automatic seismic event processing for detection and location: the P.M.C.C. method. Geophys Res Lett 22(9):1021-1024

Cansi Y, Klinger Y (1997) An automated data processing method for miniarrays. CSEM/EMSC Eur Seismol Centre, Newsl 11:1021-1024

Chadwick WW, Cashman KV, Embley RW, Matsumoto H, Dziak RP, de Ronde CEJ, Lau TK, Deardorff ND, Merle SG (2008) Direct video and hydrophone observations of submarine explosive eruptions at NW Rota-1 volcano, Mariana Arc. J Geophys Res Solid Earth 113(8):1-23. https://doi.org/10.1029/2007JB005215

Chadwick WW, Dziak RP, Haxel JH, Embley RW, Matsumoto H (2012) Submarine landslide triggered by volcanic eruption recorded by in situ hydrophone. Geology 40(1):51-54. https://doi.org/10.1130/G32495.1

Christie DR, Campus P (2010) The IMS infrasound network: design and establishment of infrasound stations. Infrasound Monitoring for Atmospheric Studies (pp. 29-75). Springer. https://doi.org/10.1007/ 978-1-4020-9508-5

Dabrowa AL, Green DN, Rust AC, Phillips JC (2011) A global study of volcanic infrasound characteristics and the potential for longrange monitoring. Earth Planet Sci Lett 310(3-4):369-379. https://doi.org/10.1016/j.epsl.2011.08.027

Dahren B, Troll VR, Andersson UB, Chadwick JP, Gardner MF, Jaxybulatov K, Koulakov I (2011) Magma plumbing beneath Anak Krakatau volcano, Indonesia: evidence for multiple magma storage regions. Contrib to Minerol Petrol 163:631-651. https://doi. org/10.1007/s00410-011-0690-8 de Groot-Hedlin CD, Hedlin MAH, Drob DP (2010) Atmospheric variability and infrasound monitoring. In Infrasound Monitoring for Atmospheric Studies (pp. 475-509). Springer

Deplus C, Bonvalot S, Dahrin D, Diament M, Harjono H, Dubois J (1995) Inner structure of the Krakatau volcanic complex (Indonesia) from gravity and bathymetry data. J Volcanol Geotherm Res 64(1-2):23-52. https://doi.org/10.1016/0377-0273(94)00038-I

Dietz RS, Sheehy MJ (1954) Transpacific detection of Myojin volcanic explosions by underwater sound. Bull Geol Soc Am 55:941-956

Dziak RP, Fox CG (1999) The January 1998 earthquake swarm at Axial volcano, Juan de Fuca Ridge: Hydroacoustic evidence of seafloor volcanic activity. Geophys Res Lett 26(23):3429-3432. https:// doi.org/10.1029/1999GL002332

Dziak RP, Park M, Matsumoto H, Byun SK (2005) Hydroacoustic records and a numerical model of the source mechanism from the first historical eruption of Anatahan Volcano, Mariana Islands. $J$. Volcanol. Geotherm. Res., 146(1-3 SPEC. ISS.), 86-101. https:// doi.org/10.1016/j.jvolgeores.2004.12.009

Dziak RP, Bohnenstiehl DR, Baker ET, Matsumoto H, Caplan-Auerbach J, Embley RW, Merle SG, Walker SL, Lau TK, Chadwick WW (2015) Long-term explosive degassing and debris flow activity at West Mata submarine volcano. Geophys Res Lett 42(5):1480-1487. https://doi.org/10.1002/2014GL062603

Eissler HK, Kanamori H (1987) A single-force model for the 1975 Kalapana, Hawaii, earthquake. J Geophys Res 92(B6):4827-4836

Evers LG, Green DN, Young NW, Snellen M (2013) Remote hydroacoustic sensing of large icebergs in the southern Indian Ocean: implications for iceberg monitoring. Geophys Res Lett 40(17):4694-4699. https://doi.org/10.1002/grl.50914

Ewing M, Worzel JL (1948) Long-range sound transmission. Mem Geol Soc Am 27:1-32. https://doi.org/10.1130/MEM27-3-p1

Fee D, Matoza RS (2013) An overview of volcano infrasound: from Hawaiian to Plinian, local to global. J Volcanol Geotherm Res 249:123-139. https://doi.org/10.1016/j.jvolgeores.2012.09.002

Fee D, Garces M, Steffke A (2010) Infrasound from Tungurahua volcano 2006-2008: Strombolian to Plinian eruptive activity. J Volcanol Geotherm Res 193(1-2):67-81. https://doi.org/10.1016/j. jvolgeores.2010.03.006

Fee D, Lyons J, Haney M, Wech A, Waythomas C, Diefenbach A, Lopez T, Van Eaton A, Schneider D (2020) Seismo-acoustic evidence for vent drying during shallow submarine eruptions at Bogoslof volcano, Alaska. Bull Volcanol 82(2)

Georges TM, Beasley WH (1977) Refraction of infrasound by upperatmospheric winds. J Acoust Soc Am 61(1):28-34. https://doi. org/10.1121/1.381263

Global Volcanism Program (1972) Card 1466 (16 October 1972). Retrieved from https://volcano.si.edu/volcano.cfm?vn=262000\& vtab=Weekly\#bgvn_197209. Accessed 24 July 2020

Global Volcanism Program (2004) Report on Epi (Vanuatu) (Venzke, E., ed.). Bulletin of the Global Volcanism Network (Vol. 29)

Global Volcanism Program (2011) Report on Krakatau (Indonesia) August 2011. Bull Glob Volcanism Netw

Global Volcanism Program (2012) Report on Krakatau (Indonesia) December 2012. Bull Glob Volcanism Netw 37(12). https://doi. org/10.5479/si.gvp.bgvn201212-262000

Global Volcanism Program (2013) Volcanoes of the World, v. 4.9.1. Venzke, E (ed.). Retrieved October 22, 2020, from https://doi.org/ 10.5479/si.GVP.VOTW4-2013

Global Volcanism Program (2017) Report on Krakatau (Indonesia) (Venzke, E., ed.). Bull Glob Volcanism Netw 42(9). https://doi. org/10.5479/si.GVP.BGVN201709-262000

Global Volcanism Program (2018) Report on Krakatau (Indonesia) (Crafford, A.E., and Venzke, E., eds.). Bull Glob Volcanism Netw 43(10). https://doi.org/10.5479/si.GVP.BGVN201810-262000

Global Volcanism Program. (2019). Report on Krakatau (Indonesia) (Krippner, J.B., and Venzke, E., eds.). (J. B. Krippner \& E. 
Venzke, Eds.), Bulletin of the Global Volcanism Network (Vol. 44). https://doi.org/10.5479/si.GVP.BGVN201903-262000

Gottschämmer E, Rohnacher A, Carter W, Nüsse A, Drach K, De Angelis, S, Lavallée Y, Kendrick JE, Roca A, Castellanos P, et al (2021) Volcanic emission and seismic tremor at Santiaguito, Guatemala: new insights from long-term seismic, infrasound and thermal measurements in 2018-2020. J Volcanol Geotherm Res 411. https://doi.org/ 10.1016/j.jvolgeores.2020.107154

Green DN, Neuberg J (2005) Seismic and infrasonic signals associated with an unusual collapse event at the Soufrière Hills volcano, Montserrat. Geophys Res Lett 32(7):1-4. https://doi.org/10.1029/2004GL022265

Green DN, Neuberg J (2006) Waveform classification of volcanic lowfrequency earthquake swarms and its implication at Soufrière Hills Volcano, Montserrat. J Volcanol Geotherm Res 153(1-2):51-63. https://doi.org/10.1016/j.jvolgeores.2005.08.003

Green DN, Evers LG, Fee D, Matoza RS, Snellen M, Smets P, Simons D (2013) Hydroacoustic, infrasonic and seismic monitoring of the submarine eruptive activity and sub-aerial plume generation at South Sarigan, May 2010. J Volcanol Geotherm Res 257:31-43. https://doi. org/10.1016/j.jvolgeores.2013.03.006

Grilli ST, Tappin DR, Carey S, Watt SFL, Ward SN, Grilli AR, Engwell SL, Zhang C, Kirby JT, Schambach L et al (2019) Modelling of the tsunami from the December 22, 2018 lateral collapse of Anak Krakatau volcano in the Sunda Straits, Indonesia. Sci Rep 9(1):1-13. https:// doi.org/10.1038/s41598-019-48327-6

Jensen FB, Kuperman WA, Porter MB, Schmidt H (2011) Computational Ocean Acoustics (Second). Springer New York Dordrecht Heidelberg London. https://doi.org/10.1007/978-1-4419-8678-8

Johnson JB, Aster RC, Kyle PR (2004) Volcanic eruptions observed with infrasound. Geophys Res Lett 31(14):21-24. https://doi.org/10.1029/ 2004GL020020

Johnson R, Norris R (1968) Geographic variation of Sofar speed and axis depth in the Pacific Ocean. J Geophys Res. https://doi.org/10.1029/ JB073i014p04695

Kanamori H, Given JW (1982) Analysis of long-period seismic waves excited by the May 18, 1980, eruption of Mt St. Helens - a terrestrial monopole? J Geophys Res 87(B7): 5422-5432

Landès M, Ceranna L, Le Pichon A, Matoza RS (2012) Localization of microbarom sources using the IMS infrasound network. J Geophys Res Atmos 117(6):1-6. https://doi.org/10.1029/2011JD016684

Lawrence MW (2004) Acoustic monitoring of the global ocean for the CTBT. Proc. of Acoustics 2004. Retrieved from http://www.acous tics.asn.au/conference_proceedings/AAS2004/ACOUSTIC/PDF/ AUTHOR/AC040084.PDF. Accessed 13 Dec 2018

Le Pichon A, Matoza RS, Brachet N, Cansi Y (2010) Recent enhancements of the PMCC infrasound signal detector. Inframatics 26:5-8

Liszka L (1974) Long-distance propagation of infrasound from artificial sources. J Acoust Soc Am 56(5):1383-1388. https://doi.org/10. $1121 / 1.1903454$

Lyons JJ, Iezzi AM, Fee D, Schwaiger HF, Wech AG, Haney MM (2020) Infrasound generated by the 2016-2017 shallow submarine eruption of Bogoslof volcano, Alaska. Bull Volcanol 82(2). https://doi.org/10. 1007/s00445-019-1355-0

Marty J (2019) The IMS infrasound network: current status and technological developments. In Infrasound Monitoring for Atmospheric Studies (pp. 3-62). Springer, Cham

Masson DG, Harbitz CB, Wynn RB, Pedersen G, Løvholt F (2006) Submarine landslides: processes, triggers and hazard prediction. Philos Trans R Soc A Math Phys Eng Sci 364(1845):2009-2039. https://doi.org/ 10.1098/rsta.2006.1810

Matoza RS, Chouet BA (2010) Subevents of long-period seismicity: implications for hydrothermal dynamics during the 2004-2008 eruption of Mount St. Helens. J Geophys Res Solid Earth 115(B12206). https:// doi.org/10.1029/2010JB007839
Matoza RS, Hedlin MAH, Garcés MA (2007) An infrasound array study of Mount St. Helens. J Volcanol Geotherm Res. https://doi.org/10.1016/j. jvolgeores.2006.10.006

Matoza RS, Fee D, Garcés MA, Seiner JM, Ramón PA, Hedlin MAH (2009) Infrasonic jet noise from volcanic eruptions. Geophys Res Lett 36(8):1-5. https://doi.org/10.1029/2008GL036486

Matoza RS, Le Pichon A, Vergoz J, Herry P, Lalande JM, il Lee H, Che IY, Rybin A (2011a) Infrasonic observations of the June 2009 Sarychev Peak eruption, Kuril Islands: implications for infrasonic monitoring of remote explosive volcanism. J Volcanol Geotherm Res 200(1-2):3548. https://doi.org/10.1016/j.jvolgeores.2010.11.022

Matoza RS, Vergoz J, Le Pichon A, Ceranna L, Green DN, Evers LG, Ripepe M, Campus P, Liszka L, Kvaerna T et al (2011b) Long-range acoustic observations of the Eyjafjallajökull eruption, Iceland, AprilMay 2010. Geophys Res Lett 38(6):1-5. https://doi.org/10.1029/ 2011GL047019

Matoza RS, Landès M, Le Pichon A, Ceranna L, Brown D (2013) Coherent ambient infrasound recorded by the International Monitoring System. Geophys Res Lett 40(2):429-433. https://doi.org/10.1029/ 2012GL054329

Matoza RS, Green DN, Le Pichon A, Shearer PM, Fee D, Mialle P, Ceranna $L$ (2017) Automated detection and cataloging of global explosive volcanism using the International Monitoring System infrasound network. J Geophys Res Solid Earth 122(4):2946-2971. https://doi.org/ 10.1002/2016JB013356

Matoza RS, Fee D, Green DN, Le Pichon A, Vergoz J, Haney MM, Mikesell TD, Franco L, Valderrama OA, Kelley MR et al (2018) Local, regional, and remote seismo-acoustic observations of the April 2015 VEI 4 eruption of Calbuco Volcano, Chile. J Geophys Res Solid Earth 123(5):3814-3827. https://doi.org/10.1002/2017JB015182

Matoza RS, Fee D, Green DN, Mialle P (2019) Volcano Infrasound and the International Monitoring System. In Infrasound Monitoring for Atmospheric Studies (pp. 1023-1077). Springer International Publishing. https://doi.org/10.1007/978-3-319-75140-5

Matsumoto H, Zampolli M, Haralabus G, Stanley J, Mattila J, Meral Özel $N$ (2019) Interpretation of detections of volcanic activity at Ioto Island obtained from in situ seismometers and remote hydrophones of the International Monitoring System. Sci Rep 9(1):1-11. https://doi.org/ 10.1038/s41598-019-55918-w

Metz D, Watts AB, Grevemeyer I, Rodgers M, Paulatto M (2016) Ultralong-range hydroacoustic observations of submarine volcanic activity at Monowai, Kermadec Arc. Geophys Res Lett 43(4):1529-1536. https://doi.org/10.1002/2015GL067259

Mialle P, Brown D, Arora N, colleagues from IDC (2019) Advances in operational processing at the International Data Centre. In Le Pichon A., Blanc E., Hauchecorne A. (eds) Infrasound Monitoring for Atmospheric Studies. Springer, Cham. https://doi.org/10.1007/ 978-3-319-75140-5_6

Modified Copernicus Sentinel Data. (2019). 2018-2019, Sentinel Hub. Retrieved June 22, 2020, from https://sentinels.copernicus.eu/docum ents/247904/690755/Sentinel_Data_Legal_Notice. Accessed 31 Aug 2020

Muhari A, Heidarzadeh M, Susmoro H, Nugroho HD, Kriswati E, Supartoyo, Wijanarto AB, Imamura F, Arikawa T (2019) The December 2018 Anak Krakatau volcano tsunami as inferred from posttsunami field surveys and spectral analysis. Pure Appl. Geophys. 176(12):5219-5233. https://doi.org/10.1007/s00024-019-02358-2

Mutschlecner JP, Whitaker RW (2010) Some atmospheric effects on infrasound signal amplitudes. In: Infrasound Monitoring for Atmospheric Studies (pp. 455-453). Springer

Nieukirk SL, Mellinger DK, Moore SE, Klinck K, Dziak RP, Goslin J (2012) Sounds from airguns and fin whales recorded in the midAtlantic Ocean, 1999-2009. J Acoust Soc Am 131(2):1102-1112. https://doi.org/10.1121/1.3672648 
Nogami K, Yoshida M, Ossaka J (1993) Chemical composition of discolored seawater around Satsuma-Iwojima, Kagoshima, Japan. Bull Volcanol Soc Japan 38(3):71-77

Okal EA (2003) T Waves from the 1998 Papua New Guinea earthquake and its aftershocks: timing the tsunamigenic slump. Pure Appl Geophys 160:1843-1863

Ossaka J (1975) The eruption of Nishinoshima submarine volcano and geochemical study of the composition of the ejecta and the volcanic activity. Chem Today (gendai Kagaku) 55:12-20 (in Japanese)

Paris A, Heinrich P, Paris R, Abadie S (2020) The December 22, 2018 Anak Krakatau, Indonesia, landslide and tsunami: preliminary modeling results. Pure Appl Geophys 177(2):571-590. https://doi.org/10.1007/s00024-019-02394-y

Perttu A, Caudron C, Assink JD, Metz D, Tailpied D, Perttu B, Hibert C, Nurfiani D, Pilger C, Muzli M et al (2020) Reconstruction of the 2018 tsunamigenic flank collapse and eruptive activity at Anak Krakatau based on eyewitness reports, seismo-acoustic and satellite observations. Earth Planet Sci Lett 541:116268. https://doi.org/10.1016/j.epsl.2020.116268

Petersen T (2007) Swarms of repeating long-period earthquakes at Shishaldin Volcano, Alaska, 2001-2004. J Volcanol Geotherm Res 166(3-4):177-192. https://doi.org/10.1016/j.jvolgeores. 2007.07.014

Przedpelski, Z. J., \& Casadevall, T. J. (1991). Volcanic ash and aviation safety: proceedings of the first international symposium on volcanic ash aviation safety, July 1991. U.S. Geol. Surv. Bull., 2047. Retrieved from https://books.google.com/books?hl=en\& $\mathrm{lr}=\& \mathrm{id}=\mathrm{qXqTc}$ sszng sC $\&$ oi $=$ fnd $\& \mathrm{pg}=\mathrm{PA} 129 \& \mathrm{dq}=$ plane + engine + ash \&ots $=$ Kq_SQ0iFh- $\&$ sig $=7$ eL5p9Ajc6KFAZU Asx4CTYoxq Yc\#v=onepage $\& \mathrm{q}=$ planeengineash $\& \mathrm{f}=$ false . Accessed 13 Dec 2018

Pusat Vulkanologi dan Mitigasi Bencana Geologi. (2018). Daily Geologic Disaster Reports (in Indonesian)

Rose KM (2020) Remote hydroacoustic and infrasonic detection and characterization of Anak Krakatau eruptive activity leading to, during, and following the December 2018 major flank collapse and tsunami (Master's thesis). University of California, Santa Barbara

Schneider DJ, Van Eaton AR, Wallace KL (2020) Satellite observations of the 2016-2017 eruption of Bogoslof volcano: aviation and ash fallout hazard implications from a waterrich eruption. Bull Volcanol 82(3). https://doi.org/10.1007/ s00445-020-1361-2

Scott KM, Macías JL, Naranjo JA, Rodríguez S, McGeehin JP (2001) Catastrophic debris flows transformed from landslides in volcanic terrains: mobility, hazard assessment, and mitigation strategies, U.S. Geological Survey Professional Paper 1630

Self S, Rampino MR (1981) The 1883 eruption of Krakatau. Nature 294(5843):699-704. https://doi.org/10.1038/294699a0

Spence RJS, Kelman I, Calogero E, Toyos G, Baxter PJ, Komorowski JC (2005) Modelling expected physical impacts and human casualties from explosive volcanic eruptions. Nat Hazards Earth Syst Sci 5(6):1003-1015. https://doi.org/10.5194/ nhess-5-1003-2005

Stehn CE (1929) The geology and volcanism of the Krakatau group. Proc Fourth Pacific Sci Congress (pp. 1-55). Batavia. Retrieved from https://scholar.google.com/scholar?hl=en\&as_sdt=0\% 2C5\&q=stehn+1929\&btnG $=$. Accessed 13 Dec 2018

Stephens CD, Chouet BA (2001) Evolution of the December 14, 1989 precursory long-period event swarm at Redoubt volcano, Alaska. J Volcanol Geotherm Res 109(1-3):133-148. https://doi.org/10. 1016/S0377-0273(00)00308-5

Strunz G, Post J, Zosseder K, Wegscheider S, Mück M, Riedlinger T, Mehl H, Dech S, Birkmann J, Gebert N et al (2011) Tsunami risk assessment in Indonesia. Nat Hazards Earth Syst Sci 11(1):67-82. https://doi.org/10.5194/nhess-11-67-2011
Sutherland LC, Bass HE (2004) Atmospheric absorption in the atmosphere up to $160 \mathrm{~km}$. J Acoust Soc Am 115(3):1012-1032. https:// doi.org/10.1121/1.1631937

Talandier J, Okal EA (2001) Identification criteria for sources of $\mathrm{T}$ waves recorded in French Polynesia. Pure Appl Geophys 158(3):567-603

Tepp G, Chadwick WW, Haney MM, Lyons JJ, Dziak RP, Merle SG, Butterfield DA, Young CW (2019) Hydroacoustic, seismic, and bathymetric observations of the 2014 submarine eruption at Ahyi Seamount, Mariana Arc. Geochemistry Geophys Geosystems 3608-3627. https://doi.org/10.1029/2019gc008311

Tepp G, Dziak RP, Haney MM, Lyons JJ, Searcy C, Matsumoto H, Haxel J (2020) Seismic and hydroacoustic observations of the 2016-17 Bogoslof eruption. Bull Volcanol 82(1). https://doi.org/ 10.1007/s00445-019-1344-3

Ulivieri G, Ripepe M, Marchetti E (2013) Infrasound reveals transition to oscillatory discharge regime during lava fountaining: implication for early warning. Geophys Res Lett 40(12):3008-3013. https://doi.org/10.1002/grl.50592

Urai M, Machida S (2005) Discolored seawater detection using ASTER reflectance products: a case study of Satsuma-Iwojima, Japan. Remote Sens Environ 99(1-2):95-104. https://doi.org/10.1016/j. rse.2005.04.028

Vergoz J, Millet C (2019) On the use of acoustic waveforms for localizing bolides: The large 2018/12/18 Bering Sea event. Infrasound Technology Workshop 2019 (ITW2019). Aqaba, Jordan

Vergoz J, Cansi Y, Cano Y, Gaillard P (2019) Analysis of hydroacoustic signals associated to the loss of the Argentinian ARA San Juan Submarine. CTBT Science and Technology (SnT) 2019 Conference. Hofburg, Vienna, Austria. Retrieved from https://ctnw.ctbto. org/ctnw/abstract/33155. Accessed 5 Nov 2020

Walter TR, Haghshenas Haghighi M, Schneider FM, Coppola D, Motagh M, Saul J, Babeyko A, Dahm T, Troll VR, Tilmann F, et al (2019) Complex hazard cascade culminating in the Anak Krakatau sector collapse. Nat Commun 10(1). https://doi.org/10.1038/ s41467-019-12284-5

Watts AB, Peirce C, Grevemeyer I, Paulatto M, Stratford W, Bassett D, Hunter JA, Kalnins LM, De Ronde CEJ (2012) Rapid rates of growth and collapse of Monowai submarine volcano in the Kermadec Arc. Nat Geosci 5(7):510-515. https://doi.org/10.1038/ ngeo1473

Wessel P, Smith WHF (1991) Free software helps map and display data. Eos Trans Am Geophys Union 72(41):441-446. https://doi. org/10.1029/90EO00319

Williams R, Rowley P, Garthwaite MC (2019) Reconstructing the Anak Krakatau flank collapse that caused the December 2018 Indonesian tsunami. Geology 47(10):973-976. https://doi.org/10.1130/ G46517.1

Williams RA, Perttu A, Taisne B (2020) Processing of volcano infrasound using film sound audio post-production techniques to improve signal detection via array processing. Geosci Lett 7(9):113. https://doi.org/10.1186/40562-020-00158-4

Wright IC, Chadwick WW, de Ronde CEJ, Reymond D, Hyvernaud O, Gennerich HH, Stoffers P, Mackay K, Dunkin MA, Bannister SC (2008) Collapse and reconstruction of Monowai submarine volcano, Kermadec Arc, 1998-2004. J Geophys Res Solid Earth 113(8):1998-2004. https://doi.org/10.1029/2007JB005138

Ye L, Kanamori H, Rivera L, Lay T, Zhou Y, Sianipar D, Satake K (2020) The 22 December 2018 tsunami from flank collapse of Anak Krakatau volcano during eruption. Sci Adv 6(3):1-10. https://doi.org/10.1126/sciadv.aaz1377

Yokoyama I (1981) A geophysical interpretation of the 1883 Krakatau eruption. J Volcanol Geotherm Res 9(4):359-378. https://doi.org/ 10.1016/0377-0273(81)90044-5 